\title{
An overview of the pterosaur assemblage from the Cambridge Greensand (Cretaceous) of Eastern England
}

\author{
David M. Unwin ${ }^{1}$ \\ With 15 figures and 2 tables
}

\begin{abstract}
The Cambridge Greensand, a remanié deposit that crops out in Cambridgeshire, eastern England, has yiclded numerous, though fragmentary, late Early Cretaceous (Albian) vertebrate fossils including more than 2000 isolated pterosaur bones. So far, 32 species of pterosaur have been proposed in connection with the Cambridge Greensand material, but there has been and continues to be considerable confusion concerning the validity of these taxa, their relationships to each other and to other pterosaurs, and the material upon which they were established. A comprehensive systematic revision identified eleven valid species distributed among three families: the Ornithocheiridae (Ornithocheirus simus and possibly a second. as yet unnamed species of Ornithocheirus, Coloborhynchus capito, Coloborhynchus sedgwickii, Anhanguera cuvieri, and Anhanguera fittoni): the Lonchodectidae (Lonchodectes compressirostris, Lonchodectes machaerorhynchus, Lonchodectes microdon and Lonchodectes platystomus); and a species of edentulous pterosaur (Ornithostoma sedgwicki) that may represent the earliest record for the Pteranodontidac. It is possible that some of the taxa currently recognised represent sexual dimorphs (Coloborhynchus capito and Coloborhynchus sedgwickii, Lonchodectes compressirostris and Lonchodectes machaerorhynchus), or disjunct populations of a single spccies (Ornithocheirus simus and Ornithocheirus sp., Lonchodectes compressirostris and Lonchodectes microdon) and that there may be as few as seven valid species, but the Cambridge Greensand pterosaurs are 100 poorly known to demonstrate this at present. The Cambridge Greensand pterosaur assemblage is similar to a slightly younger. but much smaller assemblage from the Lower Chalk of England and shares some elements, such as ornithocheirids, in common with many other late Early and early Late Cretaceous assemblages. It is distinguished by the absence of tapejarids and the presence of Lonchodectes which, so far, is only known from the Cretaceous of England. The disparity in taxonomic composition is possibly related to ecological differentiation, and might also reflect some provincialism in late Early and early Late Cretaceous pterosaur faunas.
\end{abstract}

Key words: Pterosaur, Lower Cretaceous, Cambridge Greensand, England, pterodactyloid, Ornithocheirus.

\section{Zusammenfassung}

Der Cambridge Grecnsand, eine in Ostengland aufgeschlossene Remanié-Ablagerung, hat zahlreiche Wirbeltiere aus der oberen Unterkreide (Alb) geliefert. Darunter fanden sich mehr als 2000 isolierte Pterosaurierknochen. Insgesamt wurden aus dem Greensand bis zu 32 Flugsauriertaxa beschrieben, was zu einer beträchtlichen taxonomischen und nomenklatorischen Verwirrung geführt hat, die bis heute andauert. Eine vollständige Revision erkennt 11 Arten aus drei Familien an: (1) die Ornithocheiridae (Ornithocheirus simus und vielleicht eine zweite, bislang unbenannte Art von Ornithocheirus, sowie Coloborhynchus capito, Coloborhynchus sedgwickii, Anhanguera cuvieri und Anhanguera fittoni); (2) die Lonchodectidae (Lonchodectes compressirostris, Lonchodectes machaerorhynchus, Lonchodectes microdon und Lonchodectes platystomus); und schließlich einen zahnlosen Flugsaurier (Ornithostoma sedgwicki), der zu keiner der vorgenannten Familien gehört und sich als stratigraphisch ältester Nachweis der Pteranodontidae erweisen könnte. Es ist nicht auszuschließen. dass einige der gegenwärlig erkannten Taxa eher einen ausgeprägten Sexualdimorphismus illustrieren denn taxonomisch distinkte Arten darstellen (Coloborhynchus capito und Coloborhynchus sedgwickil, Lonchodectes compressirostris und Lonchodectes nachaterorhynchus) oder sogar lediglich Endpunkte einer intraspezifisch variablen Population (Ornithocheirus simus und Ornithocheirus sp.. Lonchodectes compressirostris und Lonchodectes microdon). In dieser strengeren Fassung bestünden nur sieben gültige Arten. doch leider sind die Flugsaurier des Cambridge Greensand zu schlecht bekannt, um diese Fragen zu beantworten. Die Flugsaurierfauna des Cambridge Greensand ähnelt jüngeren kreidezeitlichen Faunen aus dem Lower Chalk von England. Weiterhin enthält sie Faunenelemente, wie etwa Ornithocheiriden, die auch für zahlreiche andere Faunen der hohen Unterkreide und tiefen Oberkreide charakteristisch sind. Das Fehlen von Tapejariden und das Auftreten des anscheinend endemischen Lonchodectes sind weitere Kennzeichen des Cambridge Greensand. Die Zusammensetzung dcr Pterosaurierfaunen folgte olfenbar ökologischen Differenzierungen und illustriert einen gewissen Provinzialismus an der Grenze Unter-Oberkrcide.

Schlüsselwörter: Pterosaurier, Unterkreide, Cambridge Greensand, England, Pterodactyloidea, Ornithocheirus.

\footnotetext{
${ }^{1}$ Museum für Naturkunde, Zentralinstitut der Humboldt-Unjversität zu Berlin, Invalidenstraße 43. D-10115 Berlin. Germany.

Received March 2001, accepted July 2001
} 


\section{Introduction}

In the mid 1800 s large scale exploitation of the Cambridge Greensand. a basal Upper Cretaceous remanié deposit that crops out in Eastern England (Worssam \& Taylor 1969). principally around Cambjidge. led to the recovery of many fossil remains including more than 2000 fragmentary, but uncrushed bones of pterosaurs. At that time, pterosaurs were still relatively poorly known and. upart from some isolated bones from the Wea den (Owen 1846) and Chalk (Bowerbank 1851. Owen 1851a. 1851b) of England. these were the first substantial remains to be recovered from the Cretaceous. The Cambridge Greensand pterosaurs were the subject of many papers by three eminent British palaeontologists: Richard Owen (1851b. 1859a. 1859b. 1860a. 1860b. 1861. 1874). Harry Seeley (1864a. 1864b. $1864 \mathrm{c} .1865 \mathrm{a}, 1865 \mathrm{~b} .1866 \mathrm{a} .1869 \mathrm{a}, 1869 \mathrm{~b}, 1870$. 1871. 1876a. 1981.1891a.1891b. 1901) and Walter Hooley (1914). These publications had a profound impact on our understanding of pterosaurs. principally with regard to their taxonomy. systematics anid evolutionary history (e.g.. Arthaber 1922. Plieninger 1930. Kuhn 1967. Wellnhofer 1978. 1991a). The three-dimensional preservation of the Cambridge Greensand bones also stood in share contrast to the compressed and flattened skeletons found in many other deposits and lent itself to a series of important functional studies (Hankin \& Watson 1914, Bramwell \& Whitfield 1974. Watson 1974, Frey \& Riess 1981). Pterosaur material from the Cambridge Greensand continues to be highly significant in that although better preserved Cretaceous pterosaur fossils have now been found, it forms the basis for a number of important taxa that are also known from other Cretaceous deposits including the Hastings Sands, Gault Clay and Chalk of England, the Kem-Kem beds of Morocco. the Crato and Santana Formations of Brazil and many others (see reviews in Wellnhofer 1991a. Unwin et al. 2000: tab. 1; Fig. 1).

The main problem posed by the Cambridge Greensand pterosaurs, and it is just as relevant today as it was for Owen. Seeley and Hooley, is the nature of their preservation. The material consists of fragmentary bones. which, although uncrushed, are rarely complete and, contrary to Seeley"s comments (e.g., 1869a), were not (or cannot now be shown to have been) preserved in association and must therefore be treated as isolated elements. Consequently, the main challenge for all those who have studied these pterosaurs has been to determine how many taxa are present and which bones belong to which taxa. Fortunately. Richard Owen established the prac-

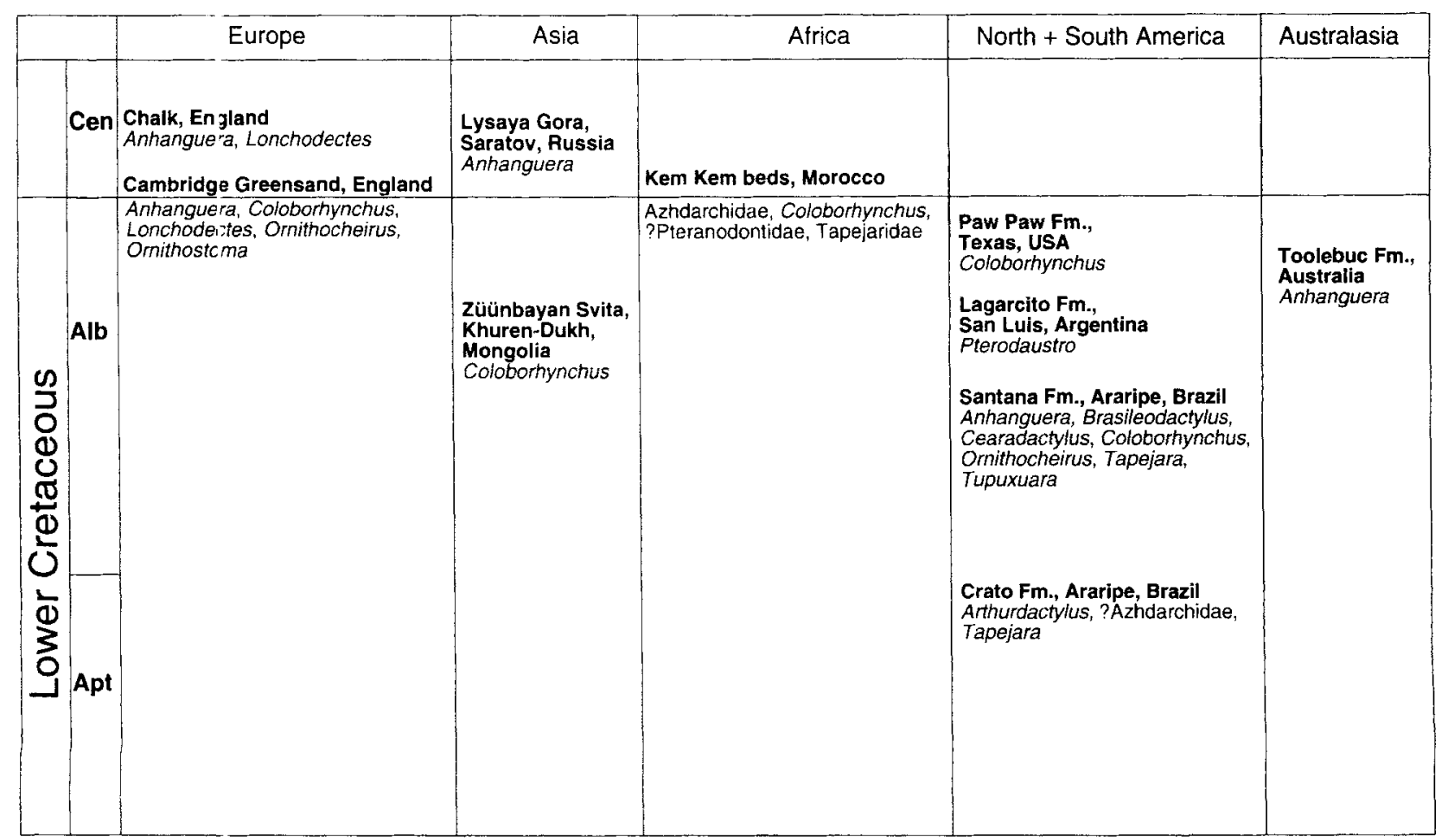

Fig. 1. Stratigraphic relationship of the Cambridge Greensand to other important late Early and early Late Cretaceous pterosaur assemblages. thbreviations: Alb. Albian: Apt. Aptian: Cen. Conomanian: Fm. Formation. 
tice of basing new species on jaw remains, since, in his opinion (e.g., Owen 1860a), the skull and jaws were the most diagnostic part of the skeleton - a proposition that has been borne out by more recent studies of pterosaurs from other deposits (e.g., Wellnhofer 1968, 1970, 1975, 1978, 1987, 1991a, 1991b, Bennett 1994, 2001, Kellner \& Tomida 2000).

Owen $(1859 \mathrm{a}, 1859 \mathrm{~b}, 1861)$ erected four species of pterosaur on the basis of the Cambridge Greensand material, three of which are still valid today (Unwin et al. 2000). Seeley published many new names (principally Seeley 1869a, 1870), both for species and for higher level taxa, but with little regard for the fledgling taxonomic procedures of the 19th century. Not surprisingly, most of his taxa are highly dubious and the manner in which Seeley proposed and then (mis)treated the few names that are valid, most notably Ornithocheirus Seeley, 1869a, confused both contemporary and subsequent workers. Hooley (1914) attempted to revise Seeley's work, but was only partially successful and some of his proposals, such as the erection of the genus Lonchodectes, though taxonomically valid, have been largely ignored. During the latter half of the 20th century various authors tried to make sense of the published material, but this generally led to further confusion. For example, in the standard work on pterosaurs, published as part of the Handbuch der Paläoherpetologie series, Wellnhofer (1978), like some earlier workers (Khozatskii \& Yur'ev 1964, Kuhn 1967), erroneously cited Pterodactylus compressirostris (= Lonchodectes compressirostris) Owen, 1851a as the type species for Ornithocheirus and the adoption of this error by some authors (e.g., Kellner 1990, Olshevsky 1991, Mader \& Kellner 1999, Kellner \& Tomida 2000) has further complicated pterosaur taxonomy.

The confusion surrounding the taxonomy and systematics of Cambridge Greensand pterosaurs continues to hinder our understanding of pterosaurs in three important ways. First, while it is evident that the fossil material from the Cambridge Greensand represents a relatively diverse and important Cretaceous pterosaur assemblage (Wellnhofer 1978, 1991a, Unwin et al. 2000), the true diversity remains unclear, as do the relationships of taxa within the assemblage to each other. Consequently, it is difficult to assess the significance of anatomical and functional studies based on Cambridge Greensand pterosaurs and also difficult to set this pterosaur assemblage within a wider ecological or evolutionary context.
Second, difficulties are posed for taxonomic assessments of other Cretaceous pterosaurs. especially those that appear to be similar to Cambridge Greensand forms. In the late 1800s, numerous, poorly founded species of Cretaceous pterosaur were assigned to Ornithocheirus, often with little or no supporting evidence, by taxonomic revisionists such as Lydekker (1888). Revision of these taxa has been difficult because of the uncertainty surrounding Ornithocheirus. Moreover, in the last three decades. many new Early Cretaceous pterosaurs have been found (summarised in Wellnhofer 1991a, Unwin et al. 2000), but, even when they show remarkable similarity to Cambridge Greensand forms, the tendency has been to assign them to new genera and species. For example, even though the corresponding region of the skull of BSP 1987 I 46 (Wellnhofer 1987: fig. 2) from the Santana Formation of Brazil is strikingly similar to the holotype of Ornithocheirus simus from the Cambridge Greensand, as some workers have noted (Unwin 1988, Fastnacht in press), Wellnhofer (1987) assigned this skull to a new genus and species: 'Tropeognathus' mesembrinus $(=$ Ornithocheirus mesembrinus).

Third, the uncertainty surrounding the taxonomic validity, systematic relationships and, consequently, the skeletal morphology of important, but poorly known taxa such as Ornithocheirus has made it difficult for researchers to incorporate Cambridge Greensand pterosaurs into phylogenetic analyses (see for example Howse 1986. Bennett 1989). This, in turn, has hindered reconstruction of the evolutionary history of pterodactyloid pterosaurs.

The account presented here represents work begun in 1984, under the supervision of the late L. B. Halstead. A principal aim was to revise the taxonomy of Cambridge Greensand pterosaurs and to utilise the results for reviewing the taxonomy and systematic relationships of other pterodactyloid pterosaurs. Much of the work on the Cambridge Greensand pterosaurs was completed by 1990 and formed the basis of a PhD dissertation (Unwin 1991). The concurrent discovery and description of relatively complete, articulated pterosaur skeletons from the Santana and Crato Formations of Brazil (reviewed by Wellnhofer 1987, 1991a, 1991b, 1991c, Campos \& Kellner 1985a, Kellner 1991, Martill \& Frey 1998. Kellner \& Tomida 2000), often representing taxa similar to or synonymous with those from the upper Lower and lower Upper Cretaceous of England (Unwin 1988, Unwin et al. 2000, Fast- 
nacht in press). was most timely and helped to resolve some key problems concerning the taxonomy and systematic relationships of the Cambridge Greensand pterosaurs. It is my intention to publish the results of this work in a series of papers covering various aspects of the Cambridge Greens and pterosaurs including their preservation. the history of research and the systematics of the major groups. This first paper presents important background material including the geology and palaeontology of the Cambridge Greensand, the preservation and taphonomy of the pterosaur assemblage. a summary of the taxonomic status of the Cambridge Greensand taxa, anc a brief discussion of the general significance of the assemblage. Further papers will provide detailed accounts of the taxonomy, anatomy and phylogenetic relationships of the Cambridge Greensand pterosaurs.

Institutional abbreviations: BMNH. The Natural History Museum. London. England; BSP, Bayerische Staatssammlung für Paläontologie und Geologie, Munich, Germany: CAMSM. Sedgwick Museum. Cambridge, England: GSM. Geological Survey Museum. Keyworth, England; MANCH, Manchester Museum, University of Manchester, Manchester, England: YORM. Yorkshire Museum, York, England.

Transliteration and taxonomic conventions: Transliteration of Russian and Mongolian names follows Benton et al. (2000). When first quoted. junior synonyms are followed by the senior synonym cited in parentheses: a full listing of synonyms and valid taxa is given in Table 1. Enclosure in single quotation marks is used to indicate taxonomic names that are imvalid or of doubiful validity. Paraphyletic taxa are distinguished by double quotation marks.

Table 1

Checklist of specits names in alphabetical order. based on plerosaur material from the Cambridge Greensand of Cambridgeshire. England. The original author and the first occasion on which the particular combination was cited is given in each case. Comments, where appropriate. are given in the right hand column. Valid names are shown in bold.

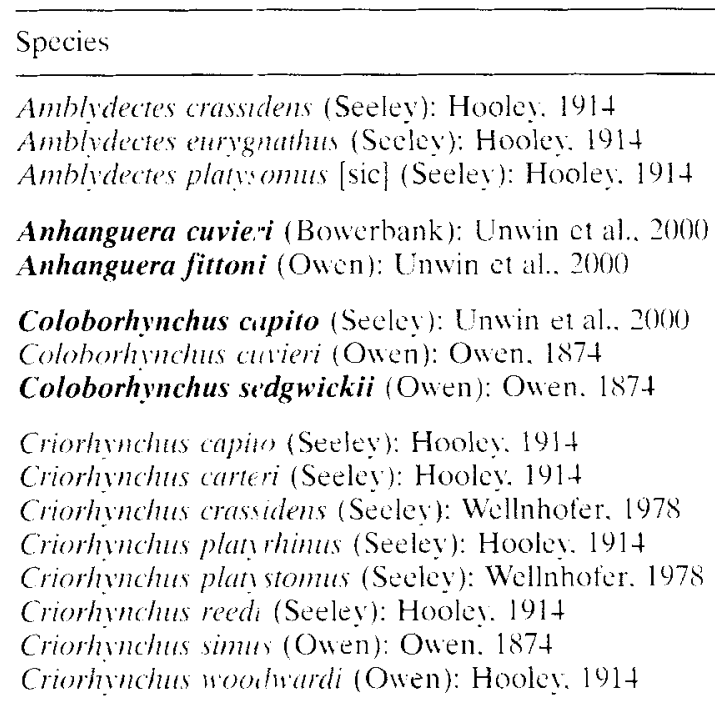

Lonchodectes com ressirostris (Owen): Hooley: 1914 Lonchodectes macinaerorhynchus (Seeley): Hooley: 1914 Lonchodectes microdon (Secley): Hoolev: $191+$ Lonchodecter oweri (Sceley): Hooley. 191t Lonchodectes plat!stomus (Seeley): Unwin et al. 2000 Lonchodectes scapiominchus (Seeley): Hooley. $191+$ Lonchodectes tenutrostris (Secley): Hooles: 19it

Onithocheirus brahyminus Secley, 1870a Ornithocheirus capito Seeley 1870 a Ornihocheinus carieri Seelev. $1869 \mathrm{a}$ Omithocheinas careri Seeley. $1870 \mathrm{a}$ Omithoheins colshimess Setey. $1870 \mathrm{a}$ Ornithocheinas crasidens Sceley. $1870 \mathrm{a}$ Ornithocheinus cureri (Bowerbank): Secley: $1870 \mathrm{a}$ Omithocheirus dentatus Seeley. $1870 \mathrm{a}$ Omithochoims denriculatus Seeley, $1870 \mathrm{a}$ Omithocheirts enciorhynchus Secles: $1870 \mathrm{a}$ Ornithocheims ear. ghathus Seeley, 1870a Omithocheirns finc, ni (Owen): Seeler: 1870a Ornithoheints haxleyi Sucley. $1870 \mathrm{a}$

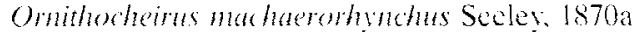
Ornithocheinas macrominus Jukes-Browne. 1875 Omithodheirus miondon Seeley. 1870 a
Status here

$$
\begin{aligned}
& =\text { Coloborhynchus sedgwickii } \\
& =\text { Coloborhynchus capito } \\
& =\text { Lonchodectes platystomus } \\
& =\text { valid spectes } \\
& =\text { valid species } \\
& =\text { valid species } \\
& =\text { Anhanguera cuvieri } \\
& =\text { valid specics } \\
& =\text { Coloborhynchus capito } \\
& =\text { Ornithocheirus simus } \\
& =\text { Coloborhynchus sedgwickii } \\
& =\text { Ornithocheirus simus } \\
& =\text { Lonchodectes platystomus } \\
& =\text { Coloborhynchus capito } \\
& =\text { Ornithocheirus simus } \\
& =\text { Coloborhynchus sedgwickii } \\
& =\text { valid species } \\
& =\text { valid species } \\
& =\text { valid species } \\
& =\text { Lonchodectes microdon } \\
& =\text { valid species } \\
& =\text { Anhanguera cuvieri }
\end{aligned}
$$

- Lonchodectes compressirostris

= Anhanguera cuvieri

= Coloborhynchus capito

$=$ nomen nudum

= Ornithocheirus simus

- Anhanguera cuvieri

= Coloborhynchus sedgwickii

- Anhanguera cuvieri

$=$ Anhanguera cuvieri

- Anhanguera cuvieri

= Anhanguera cuvieri

= Coloborhynchus capito

= Anhanguera fittoni

$=$ Lonchodectes microdon

= Lonchodectes machaerorhynchus

- nomen nudum

- Lonchodectes microdon 
Species

Ornithocheirus nasutus Seeley, $1870 \mathrm{a}$

Ornithocheirus oweni Seeley, 1870a

Ornithocheirus oxyrhinus Seeley, 1870a

Ornithocheirus platyrhinus Seelcy, 1869a

Ornithocheirus platyrhinus Seeley, 1870a

Ornithocheirus platystomus Seeley, 1870a

Ornithocheirus polyodon Seeley, 1870a

Ornithocheirus reedi Seeley, 1870a

Ornithocheirus simus (Owen): Seeley, 1869a

Omithocheirus scaphorhynchus Seeley, 1870a

Ornithocheirus sedgwickii (Owen): Seeley, 1870a

Ornithocheirus tenuirostris Seeley, 1870a

Ornithocheirus woodwardi (Owen): Seeley, 1870a

Ornithocheirus xyphorhynchus Seeley, 1870a

Ornithostoma sedgwicki Seeley, $1891 \mathrm{~b}$

Ornithostoma seeleyi Lydekker, 1904

Ptenodactylus brachyrhinus Seeley, 1869a

Ptenodactylus capito Seeley, 1869a

Ptenodactylus colorhinus Seeley, 1869a

Ptenodactylus crassidens Seeley, $1869 \mathrm{a}$

Pfenodactylus cuvieri (Bowerbank): Secley, 1869a

Ptenodactylus dentatus Seelev, $1869 \mathrm{a}$

Ptenodactylus enchorhynchus Seelcy, $1869 \mathrm{a}$

Ptenodactylus eurygnathus Seeley, $1869 \mathrm{a}$

Ptenodactylus fittoni (Owen): Seeley, 1869a

Ptenodactylus machaerorhynchus Seeley, 1869a

Pfenodactylus macrorhinus Seeley, 1869a

Ptenodactylus microdon Seeley, 1869 a

Ptenodacty/us nasutus Seeley, 1869a

Ptenodactylus oweni Secley, 1869a

Ptenodactylus oxyrhinus Secley, 1869a

Ptenodactylus platystomus Sceley, 1869a

Ptenodactylus polyodon Seeley, 1869a

Ptenodactylus scaphorhynchus Seeley, 1869a

Ptenodactylus sedgwicki [sic] (Owen): Seeley, 1869a

Ptenodactylus tenuirostris Sceley, 1869a

Ptenodactylus woodwardi (Owen): Secley, 1869a

Pterodactylus carteri Seeley, $\mathbf{1 8 6 5 b}$

Pterodactylus cuvieri Bowerbank: Seeley, 1865b

Pterodactylus fittoni Owen, $1859 \mathrm{~b}$

Pterodactylus hopkinsi Seeley, 1864b

Pterodactylits huxleyi Seelcy, 1865b

Pterodactylus machaerorhychus Seeley, 1864 a

Pterodactylus oweni Seelev, $1864 \mathrm{~b}$

Pterodactylus sedgwickii Owen, $1859 \mathrm{~b}$

Pterodactylus simus Owen, 1861

Pterodactylus woodwardi Owen, 1861
Status here

= Anhanguera fittoni

= Lonchodectes microdon

$=$ nomen nudum

$=$ nomen nudum

= Ornithocheirus simus

= Lonchodectes platystomus

$=$ Anhanguera fittoni

= Coloborhynchus capito

$=$ valid species

$=$ Anhanguera cuvieri

$=$ Coloborhynchus sedgwickii

$=$ Lonchodectes compressirostris

$=$ Coloborhynchus sedgwickii

= Anhanguera cuvieri

$=$ valid species

= Ornithostoma sedgwicki

$=$ nomen nudum

$=$ nomen nudum

$=$ nomen nudum

$=$ nomen nudum

= Anhanguera cuvieri

$=$ nomen nudum

$=$ nomen nudum

= nomen nudum

= Anhanguera fittoni

$=$ nomen nudum

$=$ nomen nudum

$=$ nomen nudum

= nomen nudum

$=$ nomen nudum

= nomen nudum

= nomen nudum

= nomen nudum

$=$ nomen nudum

$=$ Coloborhynchus sedgwickii

= nomen nudum

= Coloborhynchus sedgwickii

$=$ nomen nudum

= Anhanguera cuvieri

= Anhanguera fittoni

$=$ nomen nudum

$=$ nomen nudum

$=$ nomen nudum

$=$ nomen nudum

= Coloborhynchus sedgwickii

= Ornithocheirus simus

= Coloborhynchus sedgwickii

\section{A brief history of the study of Cambridge Greensand pterosaurs}

The first pterosaur remains to be reported from the Cambridge Greensand, three fragmentary wing bones, were described by Richard Owen (1851b: pl. xxxii, figs 6-8). Although these bones are not now of any particular taxonomic or anatomical significance they were important in the mid-nineteenth century because they provided some of the earliest evidence for the existence of large pterosaurs that reached wingspans of up to $4-5 \mathrm{~m}$. The great Cambridge Greensand coprolite mining rush (Grove 1976), which saw intensive exploitation of the deposit from the 1850 s to the $1870 \mathrm{~s}$, led to the recovery of many fossil remains including over 2000 pterosaur bones. Most of the pterosaur bones were acquired by the Sedgwick Museum (then the Woodwardian Museum), Cambridge, but important collections were also built up in other British museums including Brighton (Booth Museum), Glasgow (Hunterian Museum), London (Natural History Museum), Manchester (Manchester Museum), Norwich (Castle Museum) and York (Yorkshire Museum) and by the British Geological Survey, now in Keyworth, Nottinghamshire. Small collections also found their way 
to local muse ums in the U.K. and some large institutions ontside the U.K. including the $\mathrm{Mu}$ seum d'Histore Naturelle in Paris. France. the Bayerische Staatssamlung für Paläontologie in Munich. Germany and the Peabody Museum. Yale, USA.

Initially, the pterosaur material was studied by Richard Owen who published a series of papers (Owen 1859a. 1859b. 1860b. 1861) on more than 60 specimens loaned from the Sedgwick Museum. Owen described all the pterosaur bones under the name Pterodactylus. and identified four new species: Pterodactylus sedgwickii (= Coloborhynch is sedgwickii) Owen. 1859a. Pterodactylus fittori ( $=$ Anhanguera fittoni) Owen. 1859a. Pteroductylus simus (= Ornithocheirus simus) Owen, 1861 and Pterodactylus woodwardi (= Coloborhynchus sedgwickii) Owen. 1861. basing them on well illustrated jaw remains and making careful comparisons. especially with material from the English Chalk.

After his arrival in Cambridge in 1859 Secley began the tas s of describing the vertebrate remains from the Cambridge Greensand. one important result of which was an extensive series of publication: on the pterosaurs from this deposit (Seeley 1864a. 1864b. 1864c. 1865a. 1865b. $1866 \mathrm{a}, 1869 \mathrm{a}, 1869 \mathrm{~b}, 1870,1871,1876 \mathrm{a}, 1881$. 1891a. 1891b. 1901). The most significant works were the "Index to the fossil remains of Aves. Ornithosauria and Reptilia from the Secondary System of Strata arranged in the Woodwardian Museum of the University of Cambridge" (1869a), whict formed a guide to the museum collections. and "The Ornithosauria: an elementary study of the bones of pterodactyles made from fossil remains found in the Cambridge Upper Greensand, and arranged in the Woodwardian Muse um of the University of Cambridge" (1870) intended as both a description of. and a guide to the Cambridge Greensand pterosaurs.

The "Index" is of particular importance because, in addition to the introduction of 19 new species of pter ssaur (most of them nomina nuda - see Table 11. all from the Cambridge Greensand. this work contains the first publication of the name Ornithocheirus. Seeley also proposed a second genus rame. Ptenodactylus, but this was preoccupied by Ptenodactylus Gray. 1845. Critically. the publiation of the name Ornithocheirts was accompanied by a description and to this genus Seeley assigned three species: Pterodactylus simus Owen. 1861. and two nomina nuda: 'Ornithocheirus carteri' and 'Omithocheirus pla- twhinus:. Consequently, as Pterodactylus simus Owen was the only available and valid species assigned to the genus at the time of its publication, according to the International Commission on Zoological Nomenclature (1999: Article 68.3), it automatically became the type species by monotypy. Furthermore, Seeley later stated (1881) "The other genus, Ornithocheirus, included three species, and had for its type the Pterodactylus simus of Owen ...", an act that, according to the International Commission on Zoological Nomenclature (1999: Article 70.2), invalidated subsequent attempts by Khozatskii and Yur'ev (1964), Kuhn (1967) and Wellnhofer (1978) to fixate the type species. Finally, it should also be noted that Seeley's definition of Ornithocheirus in the Index, "no teeth anterior to the palate', while brief, is (contra Kellner \& Tomida 2000) entirely consistent with the anatomy of the type specimen of Ornithocheirus simus as discussed below.

In "The Ornithosauria" Seeley (1870) gave an extensive account of the anatomy of Cambridge Greensand pterosaurs, although unfortunately the work is marred by many errors. One of the most important was the detailed description, as pterosaurian, of a remarkably bird-like braincase (Seeley 1870: pl. xi, figs 3-6), which was later assigned by Seeley (1876b) to the Cretaceous bird Enaliornis (Elzanowski \& Galton 1991). In the systematic account Seeley listed 25 species under the name Ornithocheirus: 20 from the Cambridge Greensand (including all those previously listed under the preoccupicd name Ptenodactvlus) and a further five, described by Bowerbank (1846. 1851) and Owen (1851a, 1851b) from the English Chalk.

In a supplement to "The Ornithosauria", Seeley (1871) described additional skull bones and, in a footnote, introduced the name Ornithostoma for a fragment of edentulous jaw (CAMSM B54.485) that had been previously figured by Owen (1859b: pl. iv., figs 4-5) as the proximal end of a wing-metacarpal. In his last paper on pterosaurs Owen (1874) proposed two new genera. Coloborhynchus, based on a highly distinctive jaw fragment from the Hastings Beds, west of St. Leonards-on-Sea, Sussex, England (BMNH R1822), which was made the holotype of C. clavirostris, also included two Cambridge Greensand taxa, Pterodactylus sedgwickii and Pterodactylus cuvieri. 'Criorhynchus' was proposed for the reception of Pterodactylus simus Owen. and was diagnosed in almost the same way as Ornithocheirus Seeley, 1869a. Seeley 
(1876a) and later Lydekker (1888) correctly pointed out that 'Criorhynchus' was a junior synonym of Ornithocheirus, but, unfortunately, the former name was adopted by some subsequent workers, a practice that began with Zittel (1890), and which has continued to the present day (e.g. Kellner \& Tomida 2000).

Throughout the late 1800s Seeley continued to describe aspects of pterosaur anatomy on the basis of Cambridge Greensand material (1876a, 1881, 1891a, 1891b). Most importantly, during this period, he began using Ornithostoma as a synonym of Pteranodon, an idea that was subsequently adopted by Williston (e.g., 1895, 1896, 1897) who published numerous papers on the American Niobrara pterosaurs, and who also argued for a close similarity between Ornithocheirus and Pteranodon. In his final and largest work on pterosaurs, "Dragons of the Air", Seeley used Cambridge Greensand material to illustrate many aspects of pterosaur anatomy. This work also contained the first reconstruction of the skull of Ornithocheirus, which was, in effect, an outline of Pteranodon into which Seeley had shoehorned various skull fragments (often misidentified or incorrectly oriented) from the Cambridge Greensand (Fig. 2).

Hooley (1914) made a valiant attempt to sort out the tangled systematics of the Cambridge Greensand pterosaurs. By treating the fossils as isolated elements he took a more realistic position than Seeley, but created some difficulties for himself by accepting all the species proposed by Owen and Seeley as valid taxa. The main achievement of Hooley's work was the recognition of a distinct genus, Lonchodectes, that had been noted, but left unnamed by Seeley (1901). Various Cambridge Greensand taxa including Ornithocheirus microdon (= Lonchodectes mi-

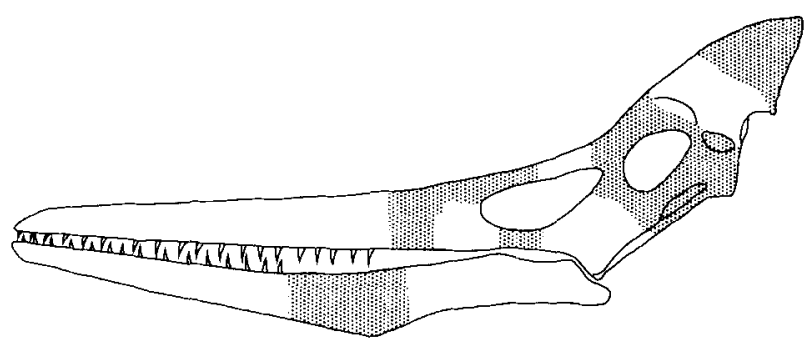

Fig. 2. The skull of Ornithocheirus, as restored by Seeley (1901). The outline of the skull appears to be based on Pteranodon and, confusingly, the missing elements are shown as shaded. Seeley identified a fragmentary cranium bearing the base of a large posterodorsally-directed crest and incorporaled it into this restoration, but never directly referred to the specimen in print. Later, Hooley (1914) assigned this specimen (CAMSM B54.406) to Ornithostoma. crodon) Seeley, 1870, and Ornithocheirus machaerorhynchus $(=$ Lonchodectes machaerorhynchus) Seeley, 1870 were assigned by Hooley to Lonchodectes which was characterised by small, uniformly spaced teeth. Hooley also argued, convincingly, that Secley's 1901 concept of Ornithocheirus was incorrect in many respects. such as the reconstruction of a large cranial crest, and that it was not Pteranodon but for the teeth, as Seeley and Williston had supposed. Hooley added to the taxonomic confusion. however, by retaining 'Criorhynchus' and synonymising Coloborhynchus with the latter taxon because he believed the differences could be attributed to the extensive attrition which the holotype of $C$. clavirostris had undergone, an interpretation which has not been supported by more recent studies (Lee 1994, Fastnacht in press).

The three-dimensional preservation of the Cambridge Greensand bones proved far more suitable for reconstructing the functional morphology of pterosaurs than the heavily compressed remains found at most other localities. Dennis (1861) and Owen (1861) both mentioned anatomical features visible in the Cambridge Greensand material that suggested to them that pterosaurs were competent fliers, but the first detailed biomechanical study was undertaken by Hankin and Watson (1914), who made some important observations on the function of the pterosaur forearm and wrist. This work was further developed by Short (1914). Subsequently. Bramwell and Whitfield in their classic study of Pteranodon (1974) utilised Cambridge Greensand material to gain insights into joint function, while Frey \& Riess (1981) also used Cambridge Greensand specimens in their controversial reconstruction of the pterosaur fore limb, especially the position of the pteroid.

After Hooley (1914), no first hand systematic studies of the Cambridge Greensand pterosaur material seem to have been attempted, and most workers in the pre-Second World War period adopted Hooley's taxonomy to varying degrees. Arthaber is of special interest because he attempted to reconstruct the skulls of some of the Cambridge Greensand taxa (Arthaber 1922: figs 5-7). Unfortunately, these restorations, notably the skull of 'Criorhynchus' simus (Fig. 3), were highly inaccurate, as Nopcsa (1924) and later workers pointed out, and as has been demonstrated by the recent discovery of a complete skull for the closely related form 'Tropeognathus' mesembrinus (Wellnhofer 1987). 


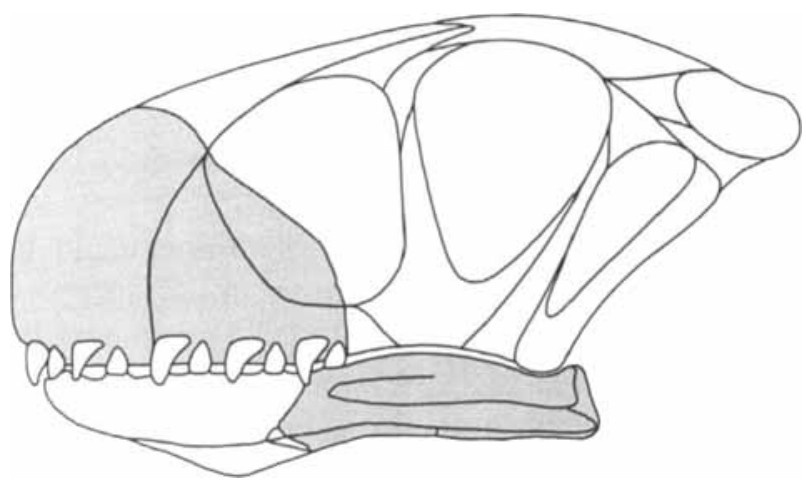

Fig. 3. The skull of Crominchus' (- Omithocheimus) as restored by Arthaber (1922).

During the ast 50 years. with the exception of the above mentioned functional studies, most accounts and conments on the Cambridge Greensand pterosaurs have been based on the early literature (principally Hooley 1914). rather than on dircet examination of the fossil material. Several general trends can be discerned. Most authors (e.g.. Kuhn 1967, Wellnhofer 1978. 1991a) recognised that some. perhaps many of the Cambridse Greensand pterosaur species were of doubtful validity. but. understandably. were unable to discriminate between valid and invalid taxa. Many authors also continued to recognise 'Criorhynchus' as a distinct taxon and even assigned it to its own family, the Criorhynchidae. while Ornithocheirus continued to act as a refuge for numerous poorly known Cretaceous pterosaurs. 'Ornithocheirus curtus', which is based on a fragmentary distal end of a wing-metacarpal (BMNH R1440) from the Wealden of Sussex (described by Owen (1870, pl. xix, figs 8-9) as the distal end of a tibia), is a typical example: this species is undiagnosable and the holotype cannot even be assigned to any particular family (Unwin 1991). Other taxa, however (such as Lonchodectes and Coloborhynchus), are based on distinct, diagnostic material and clearly cannot be accommodated within the same genus.

Kuhn (1967) and Wellnhofer (1978, 1991a) gave the most detailed systematic accounts of the Cambridge Greensand pterosaurs (Table 2) and these have formed the standard systematic arrangement followed by most other authors over the last 20 years. Description of much more complete and well preserved remains from the Santana Formation of Brazil (Wellnhofer 1985, 1991a, 1991b, 1991c, Kellner 1984, Campos \& Kellner 1985b, Kellner \& Tomida 2000) has

Table 2

Summary of systematic assessments by Kuhn (1967) and Wellnhofer (1978. 1991a) of the Cretaceous pterosaur assemblage from the Cambrid șe Greensand. England.

\begin{tabular}{|c|c|}
\hline Kuhn 1967 & Wellnhofer 1978 \\
\hline Order Ornithoche ria & \multirow{14}{*}{ 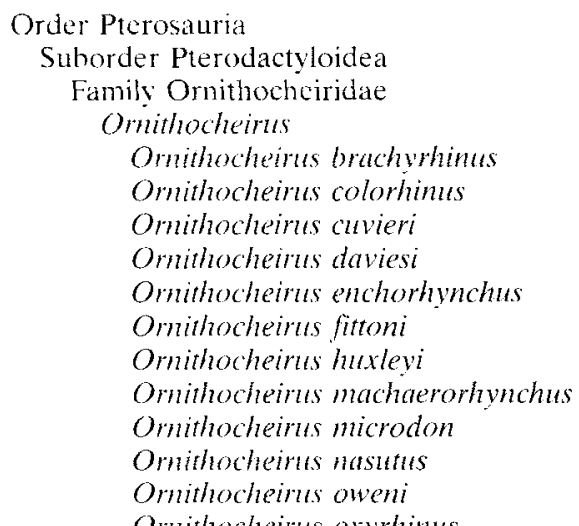 } \\
\hline Suborder Dsung̨aripteroidea & \\
\hline Family Criorhynchidae & \\
\hline Criorhynchus & \\
\hline Criohnn hus simus & \\
\hline Family Ornithocheiridac & \\
\hline Subfamily (Onithocheirinae & \\
\hline Ornithocheinus & \\
\hline Onithocheinus compressirostris & \\
\hline Subfamily F'teranodontinae & \\
\hline Ornithostma & \\
\hline & \\
\hline Well hofer 1991a & \\
\hline Suborder Pterodactyloidea & \\
\hline Family Ornithocheiridac & Ornithocheirus polyodon \\
\hline Oinithocheirus & Ornithocheirus scaphorhynchus \\
\hline Ornithocheirus curieri & Omithocheirus sedgwicki \\
\hline Ornithocheinus fittoni & Ornithocheints tentuirostris \\
\hline Onithocheirts gigantens & Omithocheirus xyphorhynchus \\
\hline Ornithocheirus microdon & Family Criorhynchidae \\
\hline Onithod eirus sedgwicki & Criorhynchiss \\
\hline other speries of Ornithocheirts & Criorhynchus capito \\
\hline Family Criorh nchidae & Criomyuchus crassidens \\
\hline Criorhynchus & Criorlynchus eurygnathus \\
\hline Criominchus simus & Criorhynchus platystomus \\
\hline other species of Crombrhothus & Crionhunchus reedi \\
\hline Family Pteranidontidae & Criorhinchus simus \\
\hline Ornithosima & Family Pteranodontidae \\
\hline Ornithe stoma seeleyi & Ornithostoma' \\
\hline
\end{tabular}


thrown some much needed light on the anatomy, taxonomy and relationships of the Cambridge Greensand pterosaurs. A critical find was the skull of 'Tropeognathus' mesembrinus (Wellnhofer 1987), which demonstrated that the holotype of Ornithocheirus simus Seeley, 1869a consists of just the anterior tip of an upper jaw bearing a large crest. Other material from the Santana Formation, such as the crania assigned to various species of Anhanguera (Campos \& Kellner 1985b, Wellnhofer 1991b, Kellner \& Tomida 2000), is strikingly similar to Cambridge Greensand specimens, but the exact relationships of the taxa based on these fossils have yet to be clarified.

\section{Geology and palaeontology of the Cambridge Greensand}

Distribution and stratigraphic relationships: The Cambridge Greensand, a remanié deposit at the base of the Chalk, crops out in a narrow, $80 \mathrm{~km}$ long swathe across East Anglia (Fig. 4). It is best developed in the region of Cambridge, from which it extends as far north as Soham in Cambridgeshire, and as far south as Harlington in Bedfordshire (Reed 1897). Large tracts of the Cambridge Greensand were ex- posed by phosphate quarrying during the nineteenth century, but in many cases these exposures were reclaimed for agricultural use (Grove 1976). Following the cessation of mining activity in the late 1800 s the number of exposures steadily declined and they are now rare (Worssam \& Taylor 1969, Norman \& Fraser 1991).

The Cambridge Greensand lies unconformably on the Gault (Reed 1897; Fig. 5). It passes upwards into what has traditionally been called the Chalk Marl, but is now referred to as the Porcellaneous beds (Morter and Wood 1983) of the Chalk Formation. Lithologically, the Cambridge Greensand has always been considered part of the Lower Chalk (White 1932, Worssam \& Taylor 1969) though much of its larger clast component is thought to have been derived from the underlying Gault (Reed 1897).

Sedimentology: The Cambridge Greensand is a thin unit of micaceous, glauconitic, silty marl, with a basal lag of reworked phosphatic nodules, remanié fossils and exotic clasts, often encrusted in small oysters (Sedgwick 1846, Seeley 1866b, Bonney 1873, Jukes-Browne 1875, Reed 1897. White 1932). The contact with the underlying Gault is an uneven and intensely burrowed erosion surface (Jukes-Browne 1875, Hart 1973;

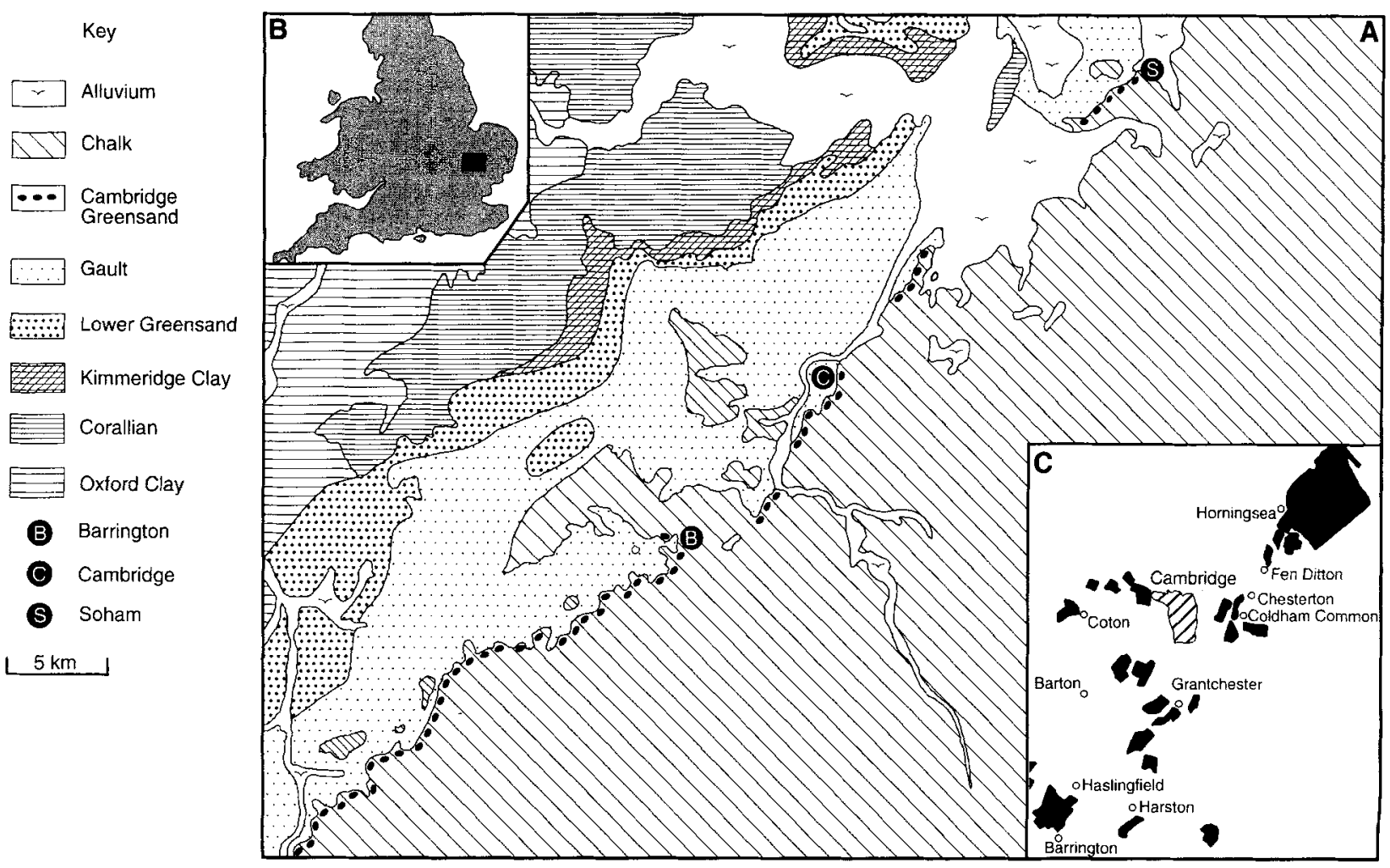

Fig. 4. A. Simplified geological map of eastern England showing the distribution of the Cambridge Greensand. B. Location of main map. C. Cambridge Greensand workings in the vicinity of Cambridge that have yielded pterosaurs. Adapted from Grove (1976) and Worssam and Taylor (1969). 
Fig. 5). The Cambridge Greensand reaches a thickness of a rout $0.6 \mathrm{~m}$ within erosional troughs (though up to $1.5 \mathrm{~m}$ has been proved in boreholes (Worssam \& Taylor 1969)), and thins to almost nothing over topographic highs of the erosive surface (Reed 1897). The basal lag. largely composed of shosphate nodules. is concentrated in depressions and while occasionally reaching up to $0.25 \mathrm{~m}$ is more usually about $0.15 \mathrm{~m}$ in thickness (White 1932).

The matrix consists of a fine chalk mud. mainly composed of coccoliths (Bonney 1873. Sollas 1876). though in some places it contains large quantities of Gault Clay (Reed 1897). The glauconitic grains. which give the unit a green tinge, seem to be derived from the Gault and prove in most cases to be internal moulds of foraminifera (Soilas 1872.1876). They are concentrated at the hase of the deposit and rapidly decrease in size and abundance upwards (White. 1932).

The phosph ate nodules have a similar distribution to the gluuconitic grains. They vary in colour from olive black through brown to pale buff (Fisher. 1873) and are usually irregularly shaped. though rounded and tubular forms also occur (Seeley 1866b). They were originally misidentified as coprol tes. which gave rise to one of the Cambridge Greensand's many alternative names. the Coprolite Bed. In fact. true coprolites. usually of fish, are rare (Seeley 1866b). Thin sections reveal that many of the nodules are the remains of phosphatised sponges (Fisher 1873. Sollas 1873). though internal moulds of molluses and phosphatised calcareous mud are also common.

Numerous exotic clasts exhibiting a wide range of lithologies and reaching up to $60 \mathrm{~kg}$ in weight. were described by early workers (Secley 1866b. Bonney 1873. Sollas \& Jukes-Browne 1873). though it was later shown that not all came from the Cambridge Greensand (Reed 1897. Hawkes 1943). These exotic clasts were probably rafted to their final resting place in tree roots (Hawkes 1943) rather than on shore ice or icebergs as exrlier authors contended (Seeley 1866b. Bonney 1873. Sollas \& Jukes-Browne 1873). although some might possibly be the dragged anchors of seaweeds (White 1932). The many rolled. water worn. phosphatised fossils that make up the remainder of the basal lag are discussed below.

Age of the Cambridge Greensand: The age of the Cambridge Greensand has long been problematic (s e White 1932. Hart 1973. Pcreda-
Suberbiola \& Barrett 1999 for historical reviews). In fact, it consists of not one, but three interrelated problems: the age of the Cambridge Greensand: the age of the remanic fauna; and the length of time represented by the non-sequence. The deposition of the bed itself is generally thought to have occurred very early in the Cenomanian. though until quite recently the only evidence for this was stratigraphic (Casey in Edmonds \& Dinham 1965). Cookson and Hughes (1964) made a case for an early Cemomanian age on the basis of three specimens of the ammonite Schloenbachia varians, but their evidence was rejected by later authors (e.g., Casey in Edmonds \& Dinham 1965, Morter \& Wood 1983). Hart (1973), using what seems to be an autochthonous fauna of foraminifera, was more successful. showing that the matrix is equivalent to the upper part of the Neostlingoceras carcitanense ammonite assemblage subzone, which is earliest Cenomanian in age (Fig. 5). The most recent study (Morter \& Wood 1983) accepted the likelihood of a basal Cenomanian age. but argued that a very late Albian age could not be ruled out. This idea was first proposed by Spath (1923-43) who believed that the bed was deposited in late Stoliczkaia dispar zone times (= Mortoniceras perinflatum subzone) and is supported by Cooper and Kennedy (1977), who noted that derived ammonites from the upper part of the $S$. dispar zone are lacking.

It is widely accepted that the remanié fossils are late Albian and not Cenomanian in age (Spath 1923-43. Cookson \& Hughes 1964. Worssam \& Taylor 1969. Morter \& Wood 1983), but there is some debate as to the duration of the non-sequence. Both Spath (1923-43) and Owen (1979) reported ammonites from as low as the basal part of the Callihoplites auritus subzone. though Morter and Wood (1983) suggested that these remains might not be from the Cambridge Greensand. A number of authors have proposed that downcutting only reached the top of the C. auritus subzone (Fig. 5) and thus the nonsequence represents the entire $S$. dispar zone (Spath 1923-43. Hart 1973, Morter \& Wood 1983). Others suggest that downcutting proceeded only as far as the top of the $A$. substuderi subzone ( $=$ top of $M$. rostratum subzone in Fig. 5) and thus only the very latest Albian, equivalent to the $M$. perinflatum subzone, is missing (Breistroffer 1940, Casey in Edmonds \& Dinham 1965. Carter \& Hart 1977). In summary, the pterosaur material can be fairly confidently dated as late Albian because there is no evi- 


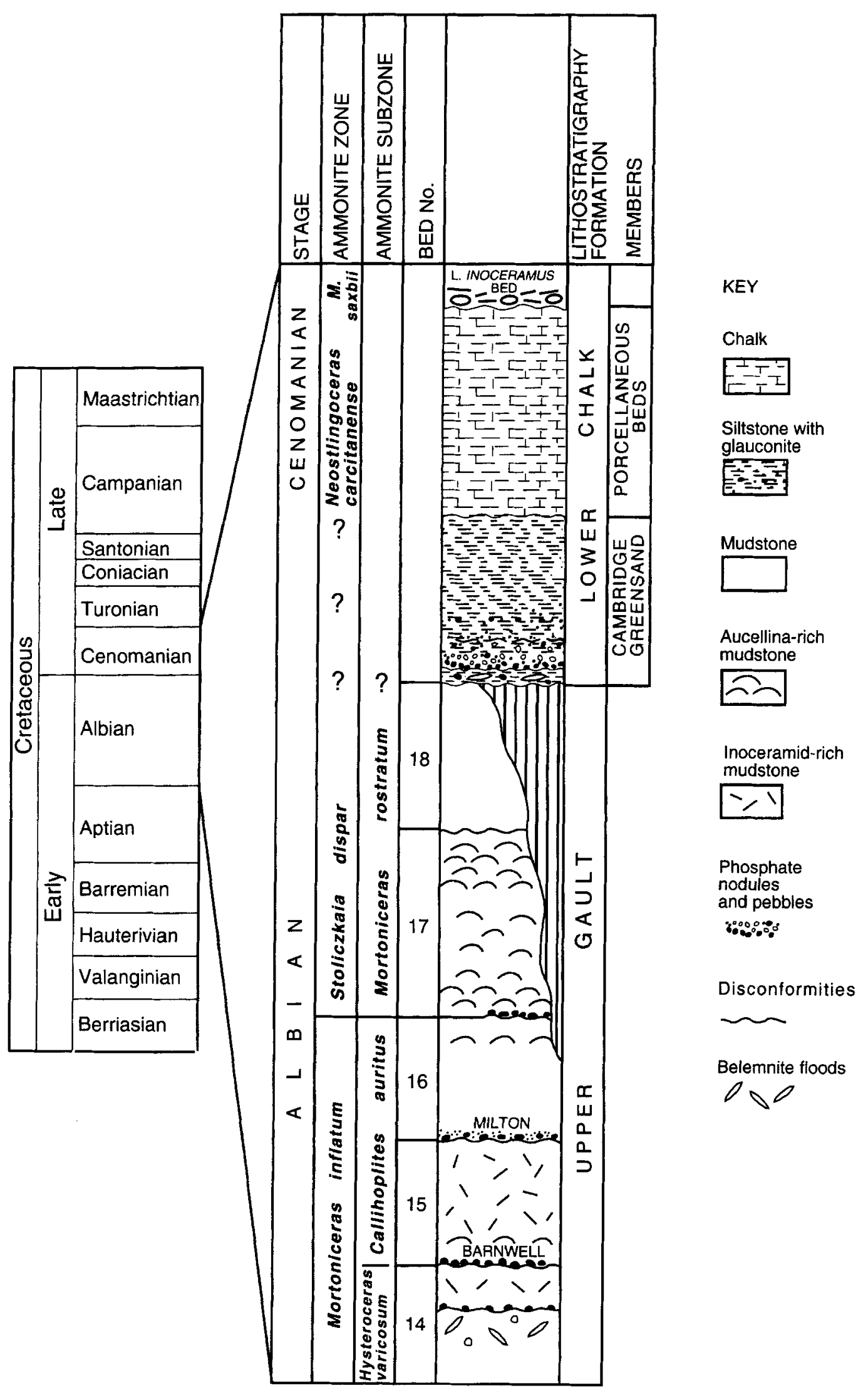

Fig. 5. Stratigraphic relationships of the Cambridge Greensand to other Cretaceous deposits in the region of Cambridge. England. Adapted from Morter and Wood (1983). Beds numbered according to Gallois \& Morter (1982). 
dence of a Cenomanian macrofauna in the Cambridge Greensand and the earliest derived remains are no older than the $C$. aluritus subzone in age.

Depositional history and palaeogeography: The Cambridge Greensand was deposited in the centre of the Anglian trough. bounded to the north by the North Norfolk swell and to the south by the Berkshire-North Kent swell (Carter \& Hart 1977: fig. 6). all of which form part of the Anglo-Paris basin. During the late Albian there was a hiatus in sedimentation associated wit 1 uplift following mild earth movements at the end of the mid-Albian (Lott et al. 1980). Curren winnowing led to the exhumation of fossil remains, exotic clasts and phosphate nodules that har been formed in the Gault Clay. All three weris rolled. concentrated and became the basal lay of the Cambridge Greensand (Reed 1897. White 1932). The absence of evidence for adult oysters encrusting clasts of the basal lag (Hat 1973) suggests relatively swift inundation by sediment. indicating that the Greensand itself was deposited quite rapidly. The sequence of events leading to the formation of the Cambridge $G$ eeensand seems to have been largely controlled by variation in sediment supply rather than hardpart input, corresponding closely to theoretical models such as Kidwell's (1986) "Type IV shell bed". which are based on this idea.

The Cambridge Greensand was deposited in a shallow epeiric sea environment, to the north and west of which lay an archipelago (Bennison \& Wright 197i3: fig. 14.4. Lott et al. 1980: fig. 15. see below). I 1 was from these islands that the exotic clasts were presumably rafted and upon which lived the various terrestrial vertebrates subsequently recovered from the Cambridge Greensand. The shallow. Anglian trough sea provided various habitats and feeding opportunities for fish. marire reptiles. diving birds and pterosaurs.

Palaeontology: In terms of both taxic diversity and numbers of individuals the Cambridge Greensand is 'ne of the single richest fossil vertebrate horizons in the British Isles. This is partly because the preservation potential was improved by phosphatisation. and partly because of the intense exploitation of the Cambridge Greensand. which led to the accumulation of large collections (Jones in Darby 1938). The fossil remains have often been divided into indigenous and derived faunas (Bonney 1873. Penning
\& Jukes-Browne 1881, Reed 1897) distinguished by differences in colour, texture and preservation. These differences may, however, be attributable to highly localised variations in preservational conditions, such as the degree to which remains were initially buried. Seeley (1876c) mentioned associated remains in which individual elements exhibited considerable variation in preservation. Hart (1973) also suggested that differences in nodule colour were of regional and not temporal significance. This hypothesis is supported by the results of this study in that no correlation was found between variation in the preservation of remains and either their size or taxonomic distribution.

Early workers published voluminous lists of taxa (Seelcy 1869a, Bonney 1873, Jukes-Browne 1875. Penning \& Jukes-Browne 1881, Woods 1891. Reed 1897), that were subsequently added to by White (1932) and Chatwin (1948). Regarding microfossils. Sollas $(1872,1876)$, Chapman (1899) and Hart (1973) described the foraminifera and Cookson and Hughes (1964) the dinoflagellates and acritarchs. The only evidence of macroflora consists of dark coloured amber (Seelcy 1866b, Reed 1897).

The rich invertebrate fauna is dominated by cephalopods, consisting mainly of ammonites (Spath 1923-43, Cooper \& Kennedy 1977), some belemnites and a few nautiloids. Bivalves and brachiopods are common, while gastropods are diverse, but not numerically abundant (Reed 1897). Echinoderms are scarce and, not surprisingly, fragmentary. Other rare groups include scaphopods, actinozoans and annelids. The carapaces of crabs and lobsters, some with evidence of parasites (Bonney 1873), are not infrequent and numerous phosphatised sponges have also been described (Sollas 1873, 1876).

This horizon has also yielded numerous, disassociated vertcbrate remains. Most, though usually uncrushed, are poorly preserved, but on occasion fine detail is exhibited. Fish make up most of the diversity with over 50 reported species. Sharks. represented by numerous teeth and spines. are common and include the ctenacanthiforms Acrodus and Hybodus, and the galeomorphs Hexanchus, Lamna, Scapanorhynchus, Squalicorax and Synechodus. Chimaeras, such as Edaphodon and Ischyodus, are also common. Woodward (1893) listed a number of pycnodonts (Athrodon. Goelodus, Anomaeodus and Pycno$d u s)$. represented by well preserved tooth plates, and also reported on scales of the semionotiform Lepidotes (Woodward 1895). Other fish include 
the pachycormid Protosphyraena and teleosts such as the ichthyodectiforms Plethodus and Saurocephalus, and the aulopiform Enchodus.

Seven genera of turtles have been recognised. Seeley (1869a) proposed new species of Emys, Trachydermochelys and Testudo, but all are nomina nuda and the remains on which they were based probably belong to Rhinochelys (Lydekker 1904). Lydekker (1889a) erected new species of Chelone, Protostega and Lytoloma on the basis of fragmentary mandibles, but it is doubtful whether any are valid (Buffetaut et al. 1981). The single remaining genus, Rhinochelys Seeley, a small to medium sized chelonioid, is represented by numerous well preserved skulls (Seeley 1869 a). Many species were established by Seeley (1869a) and Lydekker (1889a), but a systematic revision by Collins (1970) indicates that only three are valid. The abundant postcranial remains of chelonians listed by Seeley (1869a) are also probably referable to this single genus.

Seeley (1887) identified the proximal end of a femur and a first sacral as belonging to a lizard, which he named 'Patricosaurus merocratus'. Though listed by Romer (1966), this dubious taxon was ignored by Estes (1983) in his comprehensive review of lizards. Seeley (1869a, 1874) erected two new species of 'Crocodilus' on the basis of four procoelus vertebrae. Lydekker (1888) doubted they were correctly assigned to genus and Buffetaut (in Buffetaut et al. 1981) noted that the material could only be determined as Eusuchia indet.

Sauropterygians, including both plesiosauroids and pliosauroids, and represented by numerous teeth, vertebrae and a few limb bones (Owen 1851b, 1861, Seeley 1869a, 1876c), are relatively common. The various taxa proposed by Seeley (1869a, 1876c) and Lydekker (1889b) were largcly dismissed by Welles (1962) and Persson (1963), but the matcrial on which they were based would benefit from further study. The Cambridge Greensand also yielded many isolatcd teeth, fragmentary rostra, vertebrae and some limb bones of ichthyosaurs. Three genera were recognised by Seeley $(1869 a, 1873)$ and Lydekker (1889b), but all the ichthyosaur material was subsequently assigned to Platypterygius by McGowan (1972). Bardet (1992) has cast doubt on this assignment, however, and has also argued that all the species of ichthyosaur based on Cambridge Greensand material are nomina dubia.

Dinosaur remains, largely consisting of vertebrae, limb bones and a few teeth, are quite com- mon (Seeley 1869a, 1879), though very fragmentary. Six genera were recognised by Sceley (1879), but recent systematic reviews (Coombs \& Maryañska 1990, McIntosh 1990, Norman \& Weishampel 1990, Pereda-Suberbiola \& Barrett 1999) indicate that most are nomina dubia. Sauropods are represented by the titanosaurian ' $\mathrm{Ma}$ crurosaurus semnus' (Seeley 1869a, 1876d), considered by Le Loeuff (1993) to be a nomen dubium, and based on two sets of caudal vertebrae that, though discovered some miles apart, were believed by Seeley (1876d) to have come from the same individual. An associated metatarsus (Seeley 1876d) might also belong to ' $\mathrm{Ma}$ crurosaurus' (McIntosh 1990), but this material has yet to be studied in detail. A nodosaurid ankylosaur, Anoplosaurus curtonotus Seeley, 1879. represented by a partial vertebral column and appendicular elements including the shoulder girdle and fore and hind limb bones, was recently redescribed by Pereda-Suberbiola \& Barrett (1999). These authors also identified other fragmentary remains of ankylosaurs, many of which are probably referable to nodosaurids, including a partial foot and dermal plates. Other fragmentary bones appear to represent an indeterminate iguanodontian (Norman \& Weishampel 1990). A tooth, first mentioned by Seeley (1879) and later described by Lydekker (1888) under the name of 'Trachodon' cantabridgiensis, is supposedly one of the earliest records for the Hadrosauridae (Benton \& Spencer 1995, Kirkland 1998), although Head (1998) has recently questioned this identification.

A single genus of bird, Enaliornis, represented by skull fragments, vertebrae and hind limb elements was first described by Seeley (1876b) and the braincase material has recently been redescribed by Elzanowski \& Galton (1991) and Witmer (1990). Enaliornis appears to have been a specialised, foot-propelled diver (Elzanowski \& Galton 1991) and has often been allied with hesperornithids (e.g., Martin 1984), although, as shown by Elzanowski \& Galton (1991), evidence in support of this idea is not as strong as previously thought.

Pterosaurs, the most common tetrapods in the Cambridge Greensand, are discussed below.

\section{Taphonomy of the pterosaur remains}

Preservation: Unlike pterosaur bones from many other horizons, the Cambridge Greensand remains are uncrushed, but, in the vast majority 
A
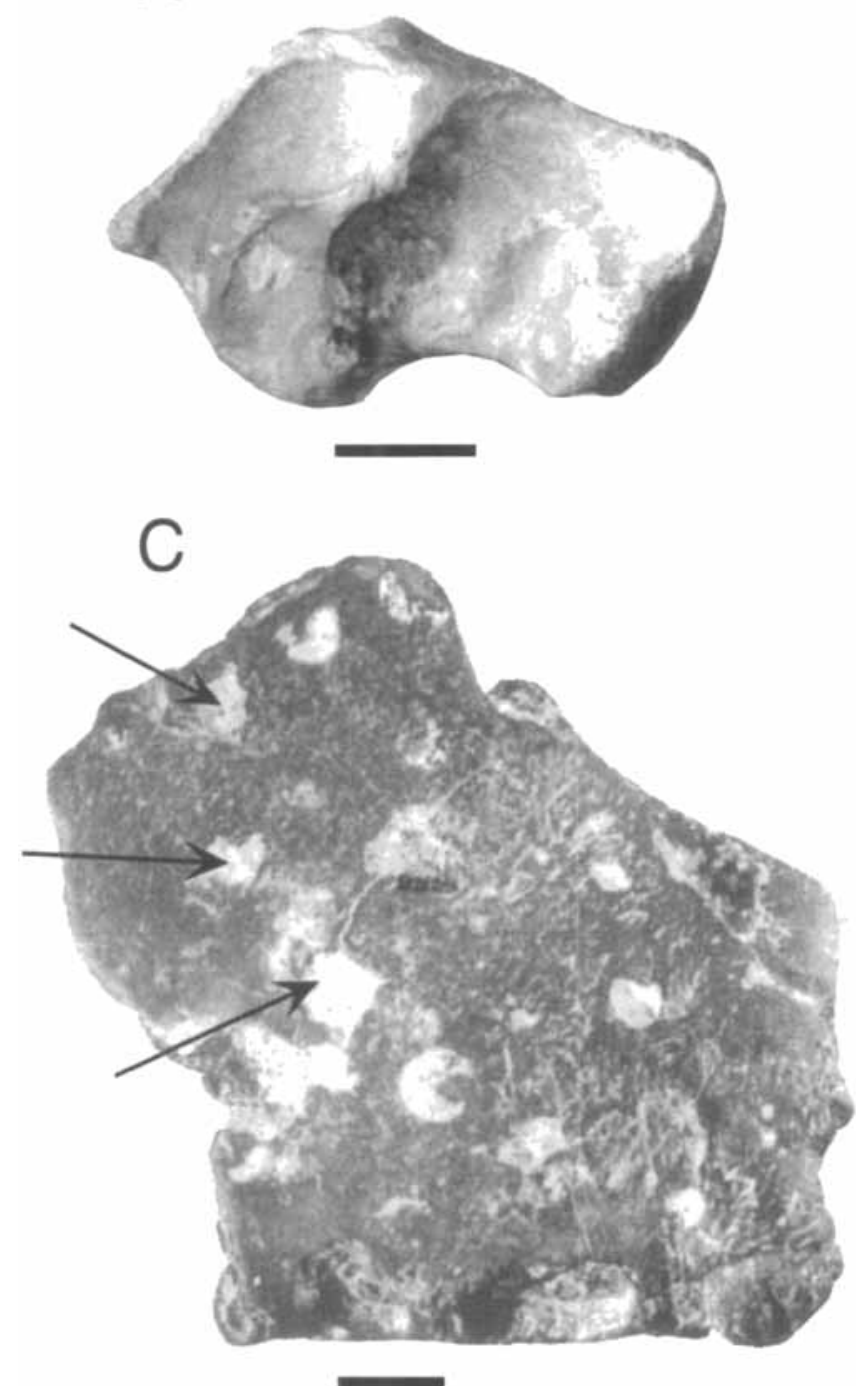

B

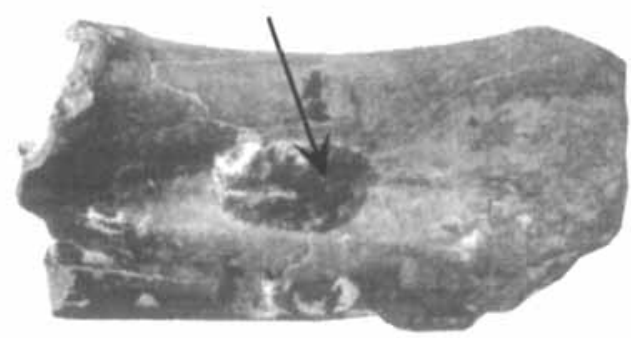

D
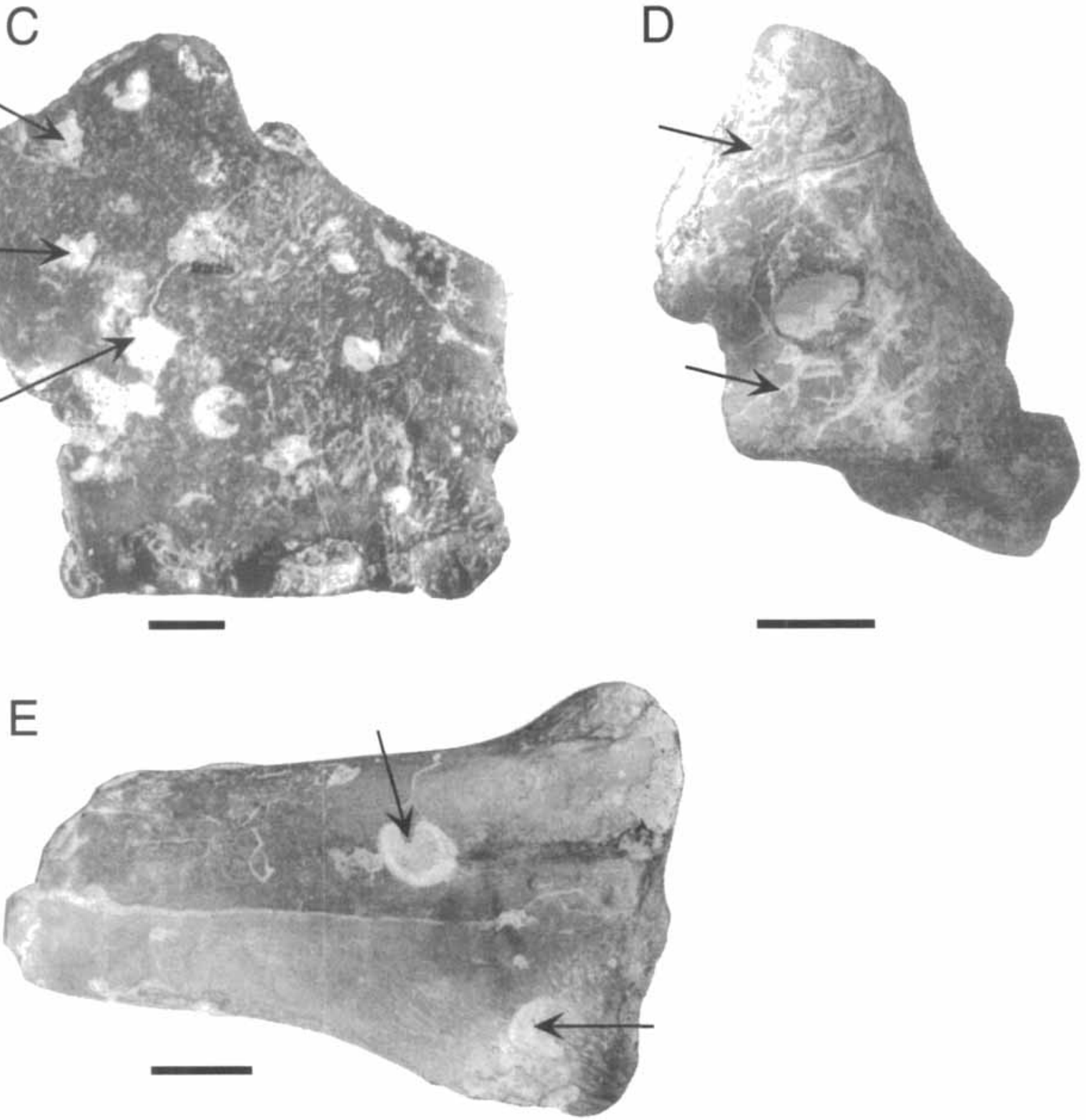

Fig. 6. Aspects of the preservation of pterosaur bones from the Cambridge Greensand (Cretaceous) of England. A. Almost perfectly preserve 1 right proximal syncarpal (BMNH R2293) in proximal view. B. Fragment of right mandible (CAMSM B54.915) of an crnithocheirid in lateral view with a small phosphate overgrowth (arrowed). C. Fragmentary rostrum (CAMSM B54.625) of Colohorhynchus capito in right lateral view with irregular pitting (arrowed) produced by ?osteopeltid gastropods. D. Frasmentary glenoid region of an omithocheirid scapulocoracoid (BMNH 35226) bearing an extensive dendritic grazing pattern (arrowed) produced by ?osteopeltid gastropods. E. Distal end of a left ulna (BMNH 35324) of an ornithocheirid in anterior view bearing attachment sites (arrowed) of small oysters. Scale bar $=10 \mathrm{~mm}$. 
of cases, they are rolled, broken and abraded. With only two or three exceptions, all long bones are incomplete, though blocky and tabular elements such as vertebrae and carpals seem to have fared better and one or two almost perfect examples are known (Fig. 6A). Most remains have suffered considerable mechanical damage, projecting processes are almost always broken off and delicate features are usually, though not always, destroyed. Teeth are either missing from their sockets or snapped off at the base.

The remains vary in colour from buff to almost black depending on the degree of mineralisation; the darkest tend to be the most heavily phosphatised. The great majority of specimens are entirely pervaded by phosphate and occasionally even overgrown by phosphate (Fig. 6B). Phosphatisation probably played an important role in increasing the resistance of remains to mechanical damage, but it should be noted that unphosphatised remains are also uncrushed.

Many remains exhibit evidence of attack from bone feeders, possibly osteopeltid gastropods, which rasp and bore away at exposed bone surlaces (Marshal 1987). Three different types of feeding ichnite have been identified. Irregular pits up to $7.5 \mathrm{~mm}$ in diameter, for example on CAMSM B54.625 (Fig. 6C), and dendritic grazing patterns, well exhibited by BMNH 35226 (Fig. 6d) and CAMSM B54.507 are common, particularly the latter, which occasionally covers entire specimens. A third and much rarer type of ichnite, exhibited by YORM 1983/220, consists of small circular pits $1-2 \mathrm{~mm}$ in diameter. Virtually all specimens were originally encrusted by small oysters, as numerous occurrences of their calcite attachment plates show (Fig. 6C, E). Most are fairly small, up to $10 \mathrm{~mm}$ in diameter, but larger ones of $20 \mathrm{~mm}$ or more are occasionally found (e.g., CAMSM B54.415). Serpulid worms also appear to have attached themselves to some of the bones (c.g., CAMSM B54.507).

A few specimens have been "repaired", but study of the components reveals that in most cases they are composites, made up of remains from different individuals. For example, the base of the tooth borne by the holotype of Ornithocheirus simus (CAMSM B54.428, Owen 1861: pl. i, figs 1-5) does not correspond in shape to the tooth socket, nor does its fracture surface match the fracture surface of the tooth preserved in the socket; this specimen is almost certainly a composite. Furthermore, two apparently complete humeri, GSM 87870 and BMNH 34413, are composites. In the first case the proximal end is from an ornithocheirid while the distal end is from a lonchodectid and in the second. the proximal end is from a right humerus and the distal end from a left.

Of greater significance, from a systematic point of view, is a list of 33 supposedly associated sets of remains, published by Seeley in the "Index to the Fossil Remains" (1869a: 8-18). These sets were purchased from the Farren brothers by the Sedgwick Muscum. Cambridge and, if genuine, as Seeley clearly believed they were, would be of considerable importance in establishing the basic characters of Cambridge Greensand pterosaurs.

There is some circumstantial evidence that associated remains were occasionally found. Secley reports seeing associated remains of plesiosaur vertebrae (1879: 592) and he also listed and described associated remains of dinosaurs and ichthyosaurs (1869a, 1876c, 1879). Moreover. Pereda-Suberbiola \& Barrett (1999) have recently described an incomplete, but apparently associated skeleton of Anoplosaurus and an associated ankylosaur foot. It is possible that these relatively heavy elements resisted movement by currents and remained in assocation, but this is unlikely to be true for pterosaur bones. which were much lighter. Moreover, the pterosaur remains exhibit considerable evidence of mechanical damage (see above), which almost certainly could not have taken place without leading to disassociation of the skeleton. Seeley (1879) argued that the damage resulted from maceration of the bones as they lay on the sea bed, but this fails to explain the broken teeth and other mechanical damage.

Study of the components of the "associated sets" removes any last doubt that they might be genuine. For example, three proximal ends of humeri are listed in set 4 (Seeley 1869a: 9). More importantly, ten sets of bones $(12-15,18$. 25-27 and 32-33) contain both large. short cervicals and vertebrae which were thought by Seeley $(1869 \mathrm{a}, 1870)$ to be caudals, but that are now known to be cervicals of a small, long-necked pterosaur (Padian 1984, 1986, Howse 1986). Associated skeletons have, as a rule, always commanded greater monetary value than single remains. It appears, therefore, that the Farrens, who were probably well aware of this, put together "associated sets" which they sold for larger sums than they would have received for individual remains, and that Seelcy uncritically accepted the purported associations of the bones. 
Taphonomic history of the pterosaur remains: The preservation of the pterosaur remains bears witness to a complex taphonomic history of which only a brief account is possible here. Following death, vertebrate carcasses usually sink fairly rapidly through the water column to the sea bed. Pterosaurs were relatively light. however, and with the additional buoyancy provided by the pneumatic system could probably float for some considerable time. Schäfer (1962) showed that diad seabirds can float for up to 40 days or more, during which time they may drift considerable cistances. Assuming that pterosaur carcasses were capable of drifting for similar lengths of time it is possible that some components of the Cambridge Greensand pterosaur fauna may have been derived from regions remote from where they finally came to rest.

Remains arrived at the sea floor either as whole carcasses, or as parts of a carcass. A variety of processes occured at this stage. Soft tissue decayed away and the remaining skeletons. either associa ed or perhaps already disassociated to some extent, were grazed upon by bone feeders. They also served as benthic islands in the soft soupy mud, providing attachment sites for bivalves and serpulid worms. It is probable that in many cases remains became partially or completely buried in the Gault Clay, only to be exhumed by current winnowing or storm activity, a cycle that may have been repeated a number of times and almost certainly led to further damage and disassociation of the remains. Phosphatisation probably took place within the sediment. with the remains acting as precipitation nuclei. The origin of the phosphate is not known, but is most likely to have been organic (Bonney 1873, Reed 1897, Norman \& Fraser 1991). Immiediately prior to the deposition of the Cambridge Greensand, the pterosaur bones. together with other vertebrate and invertebrate remains, phosohate nodules and exotic clasts seem to have been concentrated and reworked by storm eveats, which also scoured the sea floor. Any complete or articulated skeletons that had survived $t$ is far must have been broken up and disarticulated at this stage. Final burial seems to have taken place quite rapidly (Hart 1973) following resumption of sediment supply in the early Cenomanian.

While not strictly part of the taphonomic process it is worth noting that. in many cases. specimens were futher broken up by the washing processes employed during the extraction of phosphate. In addition, collecting practices and purchasing policies are likely to have further modified the original pterosaur sample.

Conclusion: This brief account of preservation and taphonomy can be used to draw a conclusion that is of special significance for investigating the taxonomy and systematics of Cambridge Greensand pterosaurs. There is no evidence to show that any of the pterosaur bones were preserved in association. Moreover, even if there were one or two such cases, which seems unlikely given the probable taphonomic history outlined above, they can no longer be demonstrated. Consequently, the associations inferred by Owen $(1859 \mathrm{a}, 1859 \mathrm{~b}, 1861)$ and listed by Seeley (1869a) must be ignored and each element must be treated as if it were an isolated find.

\section{Summary review of the taxonomy of Cambridge Greensand pterosaurs}

Thirty-two species of pterosaur have been named in connection with the Cambridge Greensand (Table 1). Most of these species are based on jaw remains (essentially the anterior ends of rostra and mandibular symphyses), but, in some cases. the name was not attached to any particular specimen and is thus a nomen nudum. Comparison of the jaw remains with each other and with other pterosaur material, principally from the Wealden, Gault Clay and Lower Chalk of England and the Santana Formation of Brazil indicates that ten of the 32 named species are valid (Table 1) and there is possibly one additional, as yet unnamed, species of Ornithocheirus. These 11 species are distributed among three families: the Ornithocheiridae, the Lonchodectidae and the ?Pteranodontidae. A brief systematic review of these families and their representatives from the Cambridge Greensand is presented here.

Ornithocheiridae: More than $90 \%$ of the identifiable pterosaur bones from the Cambridge Greensand can be assigned to the Ornithocheiridae, an important family of medium to largesized, piscivorous Cretaceous pterosaurs (Wellnhofer 1991a, Bakhurina \& Unwin 1995, Unwin \& Lü 1997. Unwin et al. 2000). The Ornithocheiridae are diagnosed by the relative proportions of the teeth in the anterior part of the dentition (Unwin 1991, Bakhurina \& Unwin 1995). The first three teeth are relatively large, forming a terminal rosette, and show a marked increase in size posteriorly. The fourth tooth pair is much 
reduced in size and smaller than the first pair of teeth. Proceeding posteriorly, there is a steady increase in tooth size up to, typically, the ninth pair, which are of similar basal dimensions to the largest teeth in the terminal rosette. Further posteriorly, tooth size declines again. Consequently, in dorsal view, the rostrum has an expanded anterior tip that accommodates the large anterior teeth, is narrowest in the region of the fourth or fifth tooth pair, and gradually widens posteriorly. The expansion of the anterior end of the rostrum is most marked in large species and adult individuals, but may be practically absent in small species and juveniles. The mandibular dentition and symphysis show similar morphological patterns to the rostrum.

At present, the Ornithocheiridae comprises Ornithocheirus and at least two additional genera: Coloborhynchus and Anhanguera (Bakhurina \& Unwin 1995, Unwin \& Bakhurina 2000, Frey \& Martill 1994, Unwin et al. 2000). Other taxa from the Santana Formation (Brasileodactylus, Araripesaurus and Santanadactylus) and the Crato Limestone Formation (Arthurdactylus) of Brazil also appear to belong within the Ornithocheiridae (Kellner 1984, Wellnhofer 1985, 1991a, Unwin et al. 2000), but their taxonomic status requires clarification because they are in at least some (and quite possibly all) cases synonymous with Anhanguera.

The Anhangueridae (Campos \& Kellner 1985b) were diagnosed in a similar way to the Ornithocheiridae and have almost the same taxonomic content (e.g., Kellner \& Tomida 2000). Evidently, the Ornithocheiridae and the Anhangueridae are synonymous, so the senior name, Ornithocheiridae, is adopted here.

In the Cambridge Greensand the Ornithocheiridae is represented by three genera: $O r$ nithocheirus, Anhanguera and Coloborhynchus. At present, ornithocheirid postcranial material cannot be assigned to any of these three genera, because, although there is some variation in the morphology of particular postcranial elements such as the humerus and ulna (Hooley 1914), it is not clear whether this variation is related to particular genera and, if so, how it is related. The discovery and description of more complete remains of ornithocheirids from the Santana and Crato Formations of Brazil may eventually enable this problem to be solved.

Ornithocheirus is one of the most common taxa in the Cambridge Greensand, and is distinguished from other ornithocheirids by characters of the dentition. Notably, the first four pairs of teeth, when observed in lateral or anterior view, are perpendicular, or near perpendicular, to the long axis of the jaw (Owen 1861: pl. i, figs 1-4, Wellnhofer 1987: fig. 2; Fig. 7). This is unlike other ornithocheirids wherein the first three to four pairs of teeth are directed forward and outward from the jaw, the degree of anterior and lateral flare decreasing posteriorly (e.g., Wellnhofer 1991b, Bakhurina \& Unwin 1995: fig. 12. Kellner \& Tomida 2000: figs 10, 11). The crest (crestless individuals are not known) is located at the anteriormost end of the rostrum (Owen 1861: pl. i, fig. 1, Wellnhofer 1987: fig. 2: Fig. 7A-C) and has a relatively flat anterior surface that rises vertically from the tip of the jaw (Fig. 7A), then curves backwards forming a high. thick, crescentic structure. The only other ornithocheirid with a crest located at the jaw tip is Coloborhynchus (see below). In this case, however, the anterodorsal surface of the crest is concave, not convex, when viewed laterally.

In the Cambridge Greensand Ornithocheirus is represented by the type species, $O$. simus, known from fragments of 13 rostra and 5 mandibular symphyses, and possibly by a second, as yet unnamed species, represented by a single specimen (CAMSM B54.890). The holotype of $O$. simus (CAMSM B54.428, Owen, 1861; Fig. 7) represents a large pterosaur that, by comparison with the more complete skull of 'Tropeognathus' mesembrinus (Wellnhofer 1987) and other ornithocheirid remains, is likely to have had a wingspan in excess of $4 \mathrm{~m}$. Most other jaw remains of $O$. simus are of a similar size to the holotype, although one or two specimens (e.g., MANCH L10832) represent somewhat larger individuals.

Chronologically, the first genus of ornithocheirid to be described from the Cambridge Greensand was Coloborhynchus (represented by Pterodactylus sedgwickii Owen, 1859a). The genus name has a somewhat complex history. It was first proposed by Owen (1874) for a new pterosaur, Coloborhynchus clavirostris, based on a highly distinctive anterior end of a rostrum from the Wealden of Hastings, Sussex (BMNH R1822). Hooley (1914) misinterpreted the jaw fragment, as Lee (1994) has pointed out, arguing that it had suffered considerable abrasion, and that originally it had the same morphology as the holotype of Ornithocheirus simus, wherein the teeth projected vertically from the palatal surface of the rostrum (Hooley 1914: pl. xxii, fig. 5). Apart from some enlargement of the dental alveoli, the rostrum is not abraded, however (Lee 1994), and the unusual morphology where- 

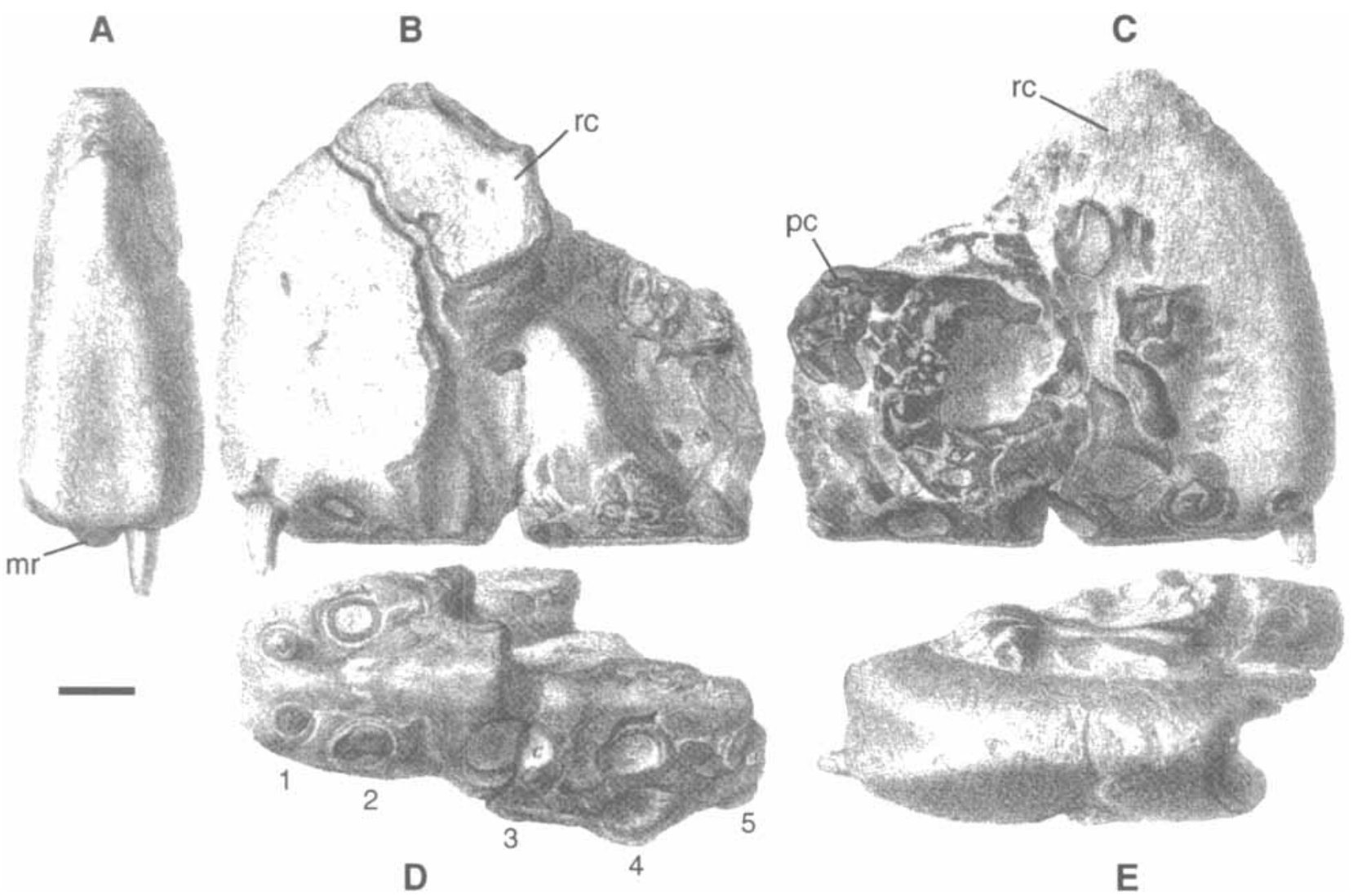

Fig. 7. Antrior end of the holotipe rostrum (CAMSM B.54.28) of Omithocheines simus (Seeley, 1869a) in (A) anterior, (B) left lateral. (C) right lateral. (D) ventral (palatal) and (E) dorsal view. Note that the tooth shown in the first left alveolus was glued in position and is not part of the holotspe specimen. Abbreviations: mr. midline ridge: pc. phosphate concretion: re, rostral crest: $1-5$. positions of first five dental alveoli. Scale bar $=10 \mathrm{~mm}$ (Modilied from Owen 1861 ).

in the palatal surface is reflected upward to form a blunt trianglılar surface terminating the antcrior tip of the rostrum. through which projects the first pair of teeth. is original and unique to this pterosaur Lee 1994. Fastnacht in press). Coloborhynchus is also distinguished from Omithocheirus by the orientation of the second and third pairs of leeth in the rostrum which are directed forwarcs and outwards. forming a tooth grab that is bounded anteriorly by the first pair of teeth. Crested forms of Coloborhynchus (one Cambridge Greensand species is crestless) are further distinglished from Ornithocheirus by the shape of the crest. as discussed above (see also Lee 1994. Fastnacht in press).

Until recently. Coloborhynchus was thought to be represented by only a single species. $C$. clarirostris, known from a single specimen from Sussex (Owen 18\%4). In 1994 Lee described a new species. C. waleighi, from the Lower Cretaceous (Albian) of Texas. again based on a single fragmentary rostrum and in 1999 Mader and Kellner described anot ier incomplete rostrum from nonmarine Cretaceous (Albian-Cenomanian) beds of Morocco as the holotype of 'Siroccopteryx' moroccensis. This fragment is virtually identical to the holotype of C. wadleighi Lee 1994, consequently 'Siroccopteryx' is treated here as a junior synonym of Coloborhynchus. Whether Coloborhinchus moroccensis can be distinguished from other species of Coloborhynchus, including the almost coeval taxa from the Cambridge Greensand. has yet to be clarified. Fastnacht (in press) has reported on a coloborhynchid from the Santana Formation of Brazil, referring an associated rostrum and mandibular symphysis to 'Tropeognathus' robustus Wellnhofer, 1987 and assigning this species to Coloborhynchus. Finally, a semicomplete skeleton of Coloborhynchus, also from the Santana Formation, is currently under study by Veldmeijer (1998).

Coloborhynchus is represented by two species in the Cambridge Greensand: C. capito Seclcy, 1870 and C. sedgwickii Owen, 1859a. Coloborhynchus capito. a crested form, known from four fragmentary rostra, including CAMSM B54.625, the holotype (Fig. 8), and possibly two fragmentary mandibular symphyses, is similar to the type species C. clavirostris, but distinguished by the much thicker and taller sagittal crest that, in lat- 
A
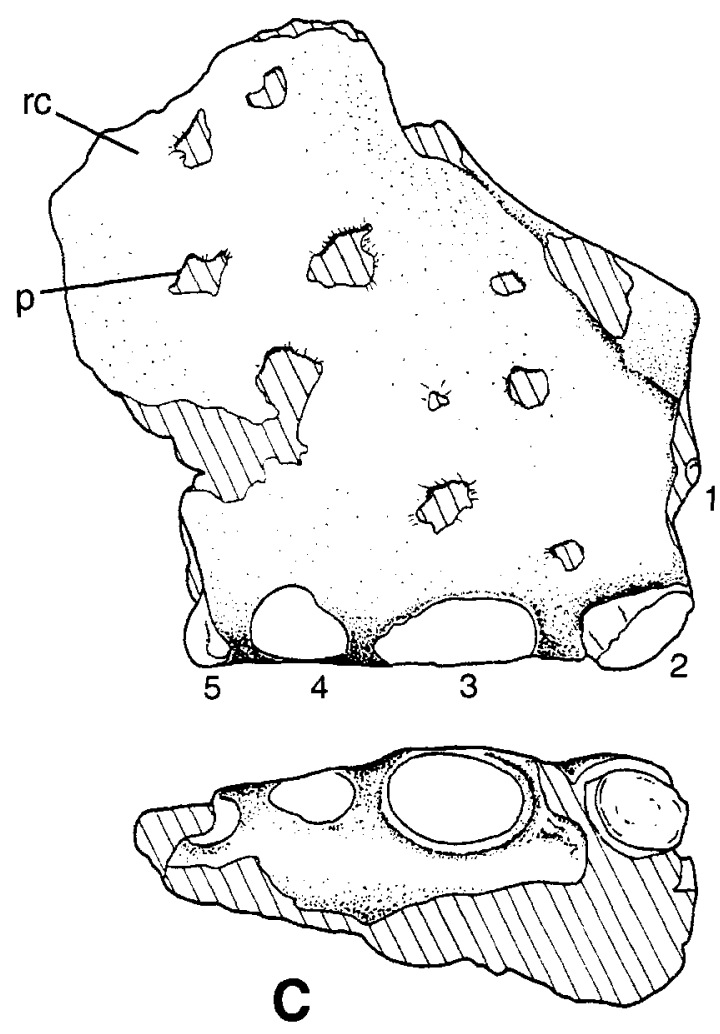

eral view, has a distinctly concave rather than flattish anterodorsal margin. Coloborhynchus capito was a large pterosaur: comparison with a relatively complete skeleton of a similar pterosaur from the Lower Cretaceous of Mongolia (Bakhurina \& Unwin 1995) indicates that the holotype represents an individual that was probably over $5 \mathrm{~m}$ in wingspan, while BMNH R481, the largest known individual, is likely to have been well over $6 \mathrm{~m}$.

Coloborhynchus sedgwickii Owen, 1859a is known from eight fragments of the anterior end
B

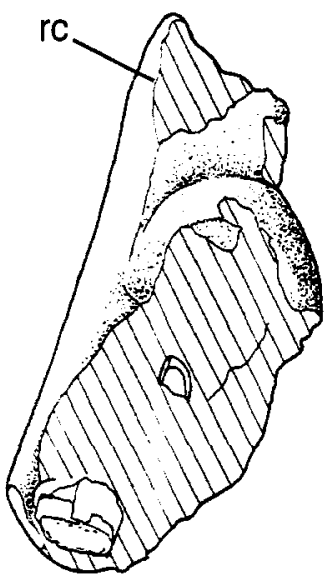

Fig. 8. Anterior end of the holotype rostrum (CAMSM B54.625) of Coloborhynchus capito (Seeley, 1870) in (A) right lateral, (B) anterior and (C) ventral (palatal) view. Abbreviations: p, pitting caused by ?osteopeltid gastropods; rc, rostral crest: 1-5. positions of first five dental alveoli. Scale bar $=10 \mathrm{~mm}$.

of the rostrum, including the holotype CAMSM B54.422 (Fig. 9), and possibly four fragments of the mandibular symphysis. The shape of the rostrum and the size and arrangement of the teeth in C. sedgwickii is similar to that seen in C. capito, and the only clear distinction between the two species is that $C$. sedgwickii lacks a rostral crest. In other pterosaurs the presence or absence of cranial crests has been interpreted as sexual dimorphism (Bennett 1992), thus it may well be that $C$. capito and $C$. sedgwickii are sexual dimorphs of a single species. Synonymy of
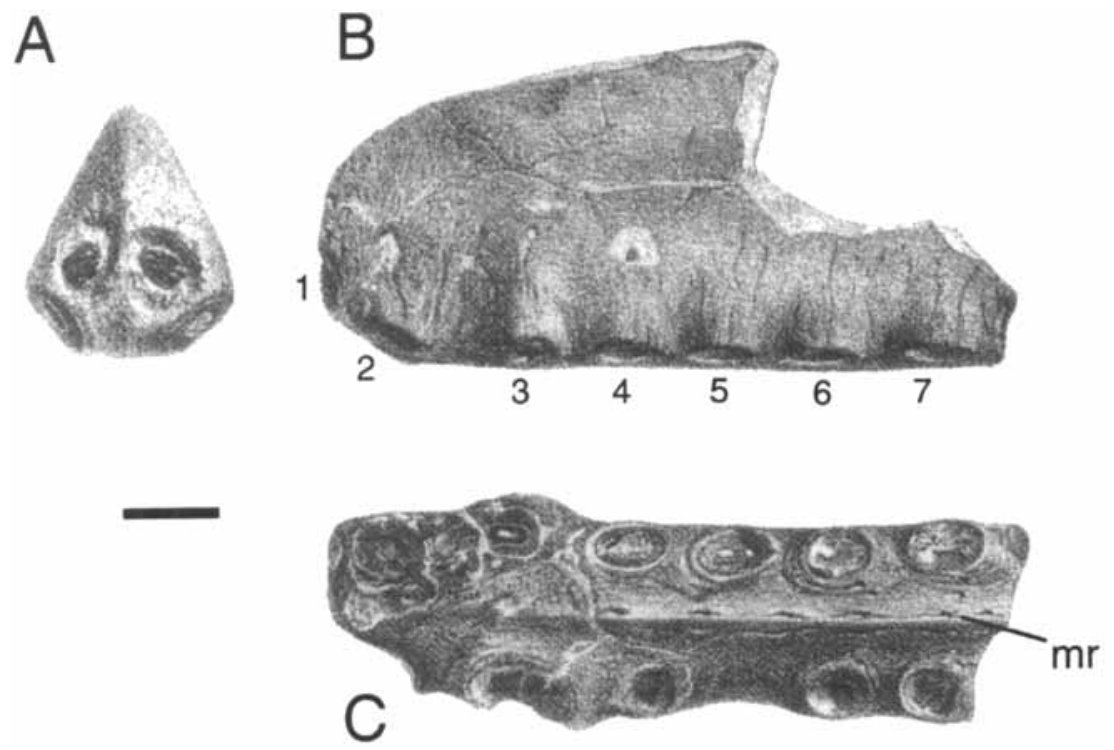

Fig. 9. Anterior end of the holotype rostrum (CAMSM B54.422) of Colo. borhynchus sedgwickii (Owen, 1859a) in $(\mathbf{A})$ anterior, (B) left lateral and (C) ventral (palatal) view. Abbreviations: mr, midline ridge: $1-7$, positions of first seven dental alveoli. Scale $\mathrm{bar}=10 \mathrm{~mm}$ (Modified from Owen 1859b). 
these two species should wait. however. until we have a better understanding of the remaining cranial and postcranial anatomy of these taxa and other coloborhynchids. and of the significance of cranial crests.

A third genus of ornithocheirid from the Cambridge Greensand is identified here as Anhanguera. This genus was first established on the basis of a skull from the Santana Formation of Brazil which was made the holotype of Anhanguera blittersd rffi (Campos \& Kellner 1985b). This, and other nominal species of Anhanguera (A. santanae. A. 'piscator'). exhibit typical ornithocheirid features such as the development of a terminal rosette of enlarged teeth. thus Anhanguera belongs within the Ornithocheiridae. The problem with Anhanguera is that it may be synonymous with previously described Santana Formation taxá such as Brasileodactylus (Kellner 1984) or. as Bennett has noted (1994: 22), with Santanadactylus (de Buisonje 1980). However. until this and cther taxonomic problems concerning Santana pterosaurs have been resolved I prefer to retain the name Anhanguera for material assigned to $A$. blittersdorffi. and other nominal species currently included in this genus (e.g. Kellner \& Torrida 2000).

Anhanguera seems to be distinct from Coloborhynchus in that while the palatal surface is also reflected upward at the anterior tip of the rostrum. the reflection is at a relatively gentle angle (about 45 . rather than 90 in Coloborhynchus) and not so abrupt. Moreover. in skulls that bear a crest. this is located somewhat posterior to the jaw tip (Kellner \& Tomida 2000: figs 4. 5. 62, 60-69), rather than at the anterior end of the jaw as in Coloborhynchus (see above). In other respects. however. such as the size. spacing and orientation of the tecth. these two genera arı remarkably similar and further work is needed to determine whether they are truly distinct (s se also Fastnacht in press).

Two species of Anhanguera. A cunieri (Bowerbank 1851) and $A$. fittoni (Owen 1859a). are currently recognised from the Cambridge Greensand. The holo ype of $A$. cuvieri (BMNH 39409). a well preserved rostrum. was collected from the Lower Chalk of Sussex and originally described under the name Pterodactylus cuvieri by Bowerbank (1851). Anhanguera cuvieri is by far the most common species of pterosaur in the Cambridge Greensand where it is represented by 23 fragments from the anterior end of the rostrum and 19 fragme ts from the anterior end of the mandibular symphysis. Anhanguera cuvieri is dis- tinguished from other species of Anhanguera by the relatively even width of the rostrum (Fig. 10A. B) and mandibular symphysis which lack the marked expansion of the anterior end seen in A. blittersdorffi (Campos \& Kellner 1985b), A. santanae (Wellnhofer 1991b) and $A$. 'piscator' (Kellner \& Tomida 2000). The large series of jaw remains of $A$. cuvieri from the Cambridge Greensand includes some juvenile individuals. and numerous sub-adults/adults, typically of about the same size as the holotype specimen. which. on the basis of comparisons with more complete remains of Anhanguera from the Santana Formation (Wellnhofer 1991c, Kellner \& Tomida 2000) had an estimated wingspan of about $3.5 \mathrm{~m}$. Some specimens, such as CAMSM B54.431 (Fig. 10A. B), represent substantially larger individuals that may have reached wingspans of up to $5 \mathrm{~m}$.

The second species of Anhanguera, A. fittoni (Owen 1859b) is represented by five fragments of the anterior end of the rostrum (Fig. 10C-G), including the lectotype (CAMSM B54.423, Owen 1859b: pl. i, figs $3 \mathrm{a}-\mathrm{c}$; Fig. 10F, G) and possibly two fragments of the anterior end of the mandibular symphysis. Anhanguera fittoni is distinguished by the broad, flattened and spatulate jaw tips that are blunter and rounder, with relatively more widely separated tooth rows than in other species. Assuming that the skeletal proportions wore similar to other species of Anhanguera then. typically, individuals of $A$. fittoni were probably about $3-3.5 \mathrm{~m}$ in wingspan.

Lonchodectidae: This is a poorly known family of small to medium-sized (probably about $1-2 \mathrm{~m}$ wingspan) relatively non-derived pterodactyloids recorded, so far, only from the late Lower and early Upper Cretaceous of southern England (Fig. 1). Lonchodectids are distinguished by features of the jaws and dentition including: dorsoventrally flattened jaw tips; distinctive straight, narrow, parapet-like dental margins; and small, round. subequally-sized dental alveoli with margins that are raised into a low collar so that the teeth appear to be pedicellate (e.g., Owen $1851 \mathrm{~b}$ : pl. xxxi, figs 1-7, 1874: pl. ii, figs 1-8. Hooley 1914: 535).

Lonchodectids have elongate cervical vertebrae with low neural spines (Owen 1860b: pl. i, figs $35-37,1861$ : pl. ii, figs $13-16$ ) and a relatively underived pterodactyloid humerus with a straight deltopectoral crest (Seeley 1870: pl. iv, figs 1.2. 7-11). Thus they are certainly not ornithocheiroids which have short, deep cervicals 
A

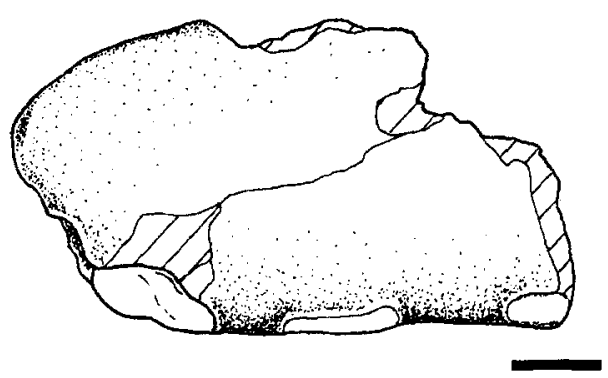

B

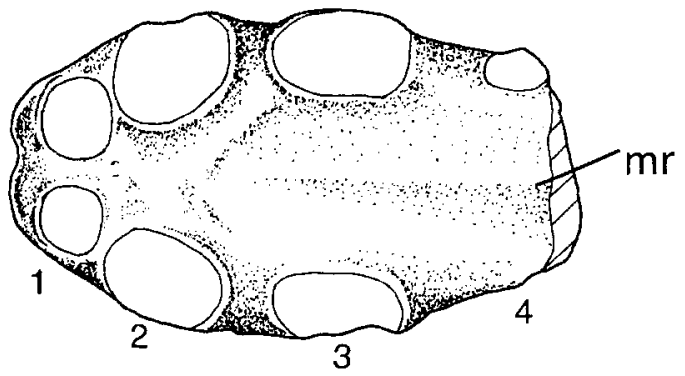

C
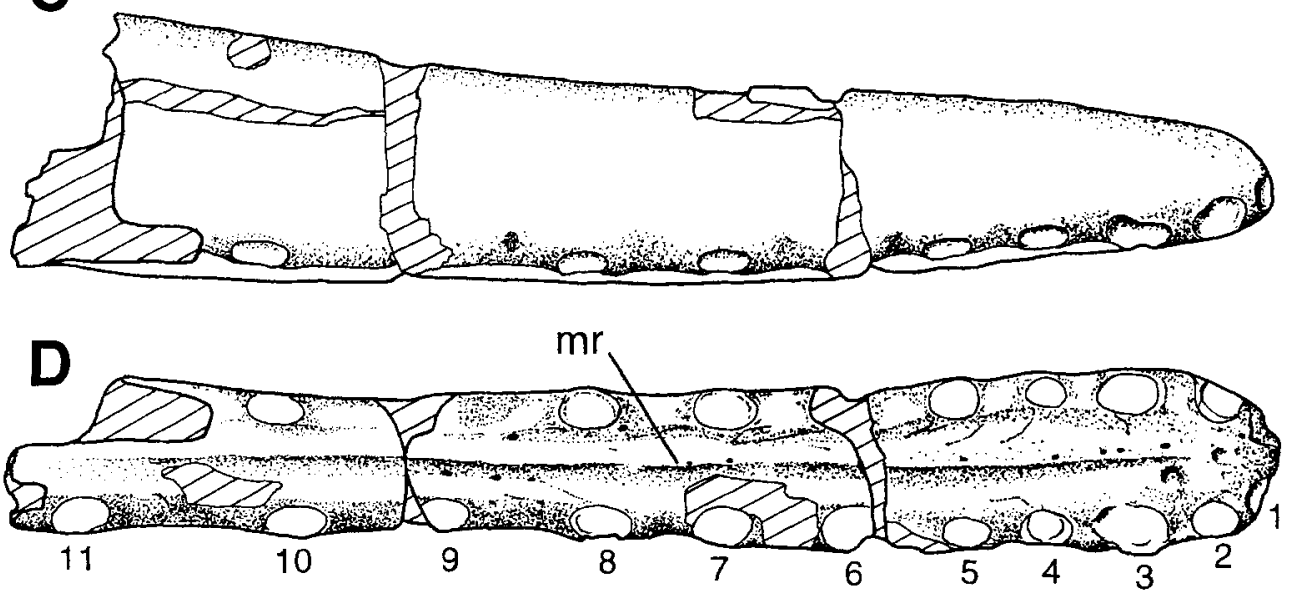

$\mathbf{E}$

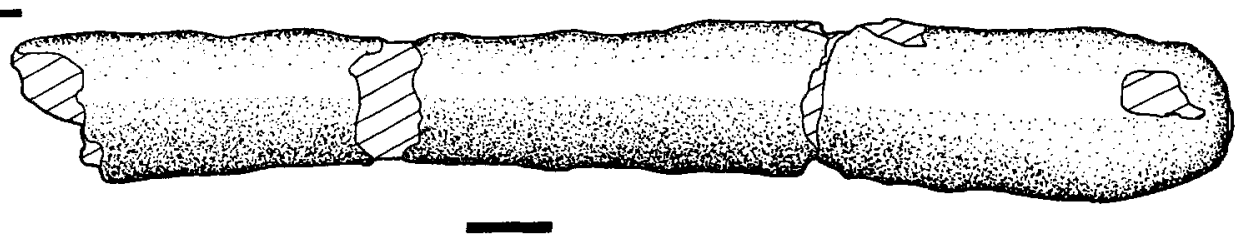

$\mathbf{F}$
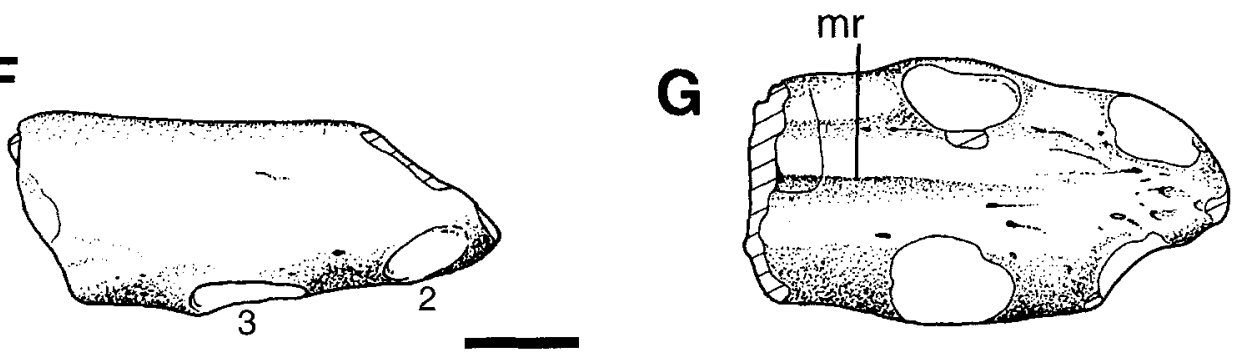

Fig. 10. Anterior end of the rostrum (CAMSM B54.431) of a large individual of Anhanguera cuvieri in (A) left lateral and (B) ventral (palatal) view. Anterior end of the rostrum (CAMSM B54.556) of Anhanguera fittoni in (C) right lateral. (D) ventral (palatal) and (E) dorsal view. Anterior end of the lectotype rostrum (CAMSM B54.423) of Anhanguera fittoni in (F) right lateral and (G) ventral (palatal) view. Abbreviations: mr, midline ridge: 1-11. positions of first eleven dental alveoli. Scale bar $=10 \mathrm{~mm}$

with tall neural spines and a twisted deltopectoral crest on the humerus (Padian 1986, Bennett 1989, Unwin \& Lü 1997). The relationships of the Lonchodectidae to the major non-ornithocheiroid clades (Ctenochasmatoidea, Dsungaripteroidea and Azhdarchoidea) are not clear and, for the present, they are placed in an unresolved trichotomy with Ctenochasmatoidea and Dsungaripteroidea + Azhdarchoidea (Fig. 14, see below).

Currently, the earliest record for the Lonchodectidae is 'Pterodactylus' sagittirostris (= Lonch- 
odectes sagitti ostris). based on a single, incomplete lower jaw from the Hastings Sands of Sussex (Owen 1874). Lonchodectids are best known from the Cambridge Greensand which has yielded nine jaw remains. representing. at most. four species (able 1). and a series of postcranial bones, including fragmentary vertebrae and fore and hind limb elements (Hooley 1914. Unwin et al. 2000 )

Lonchodect ds have also been found in the Lower Chalk of Kent. England, where they are represented by two species: Lonchodectes giganteus (Bowerbank 1846) and L. compressirostris (Owen 1851a). Lonchodectes gigantets is the only lonchodectid known so far in which the upper and lover jaws are preserved in association and has orominent rostral and mandibular crests (Owen 1851b: pl. xxxi, figs 1-7). Although it has been assumed that $L$. giganteus had short. deep jaws (e.g., Wellnhofer 1978), this species probably had an elongate rostrum and mandibular symphysis as in other lonchodectids. The holotype of L. compressirostris (BMNH 39410) appears to have a narrow, blade-like tip to the rostrum (Owen 1851b: pl. xxviii, figs $8-10)$, unlike the rather spatulate jaw tip of other lonchodectids. The anterior portion of the rostrum is heavily compressed, however, and originally was probably much flatter and broader.

In the Cambridge Greensand Lonchodectes compressirostris is represented by a single fragment of the rostrum (CAMSM B54.584; Fig. $11 \mathrm{~A} . \mathrm{B})$ that is identical to the holotype specimen from the Chalk. A second Cambridge
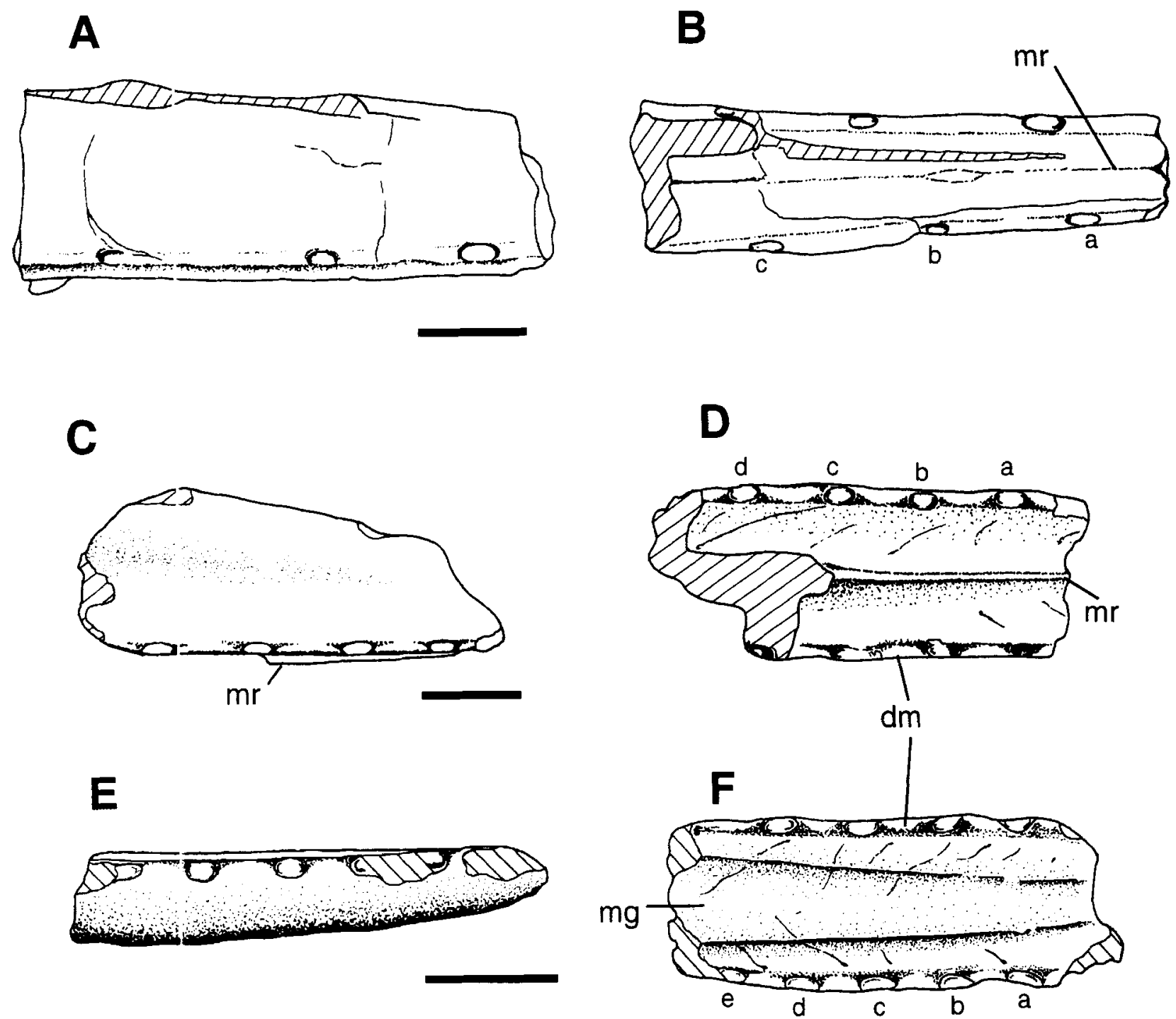

Fig. 11. Scetion of the rostrum (CAMSM B54.584) of Loncholectes compressirostris in (A) right lateral and (B) ventral (palatal) view. Section of the holotype rostrum (CA.MSM B.54.486) of Lonchodectes microdon in (C) right lateral and (D) ventral (palatal) view. Anterior end of the mandibular stmphysis (BMNH R2269) of Lonchodectes microdon in (E) right lateral and $(\mathbf{F})$ do sal view. Abbreviations: a-e. positions of fice consecutive dental alveoli: dm, dental margin: mg, midline groove: mr. midlin : ridge. Scale bar $=10 \mathrm{~mm}$. 
Greensand species, Lonchodectes microdon, represented by fragments from both the rostrum and the mandibular symphysis (Fig. $11 \mathrm{C}-\mathrm{F}$ ), is probably synonymous with $L$. compressirostris, although this synonymy cannot be satisfactorily demonstrated on the basis of existing material. A third Cambridge Greensand species, L. machaerorhynchus, is represented by a single, fragmentary mandibular symphysis (CAMSM B54.855) that is similar to material assigned to $L$. microdon, but distinguished by the presence of a prominent triangular median crest (Fig. 12D, E). A fourth species, L. platystomus, which is also known from the English Gault (Owen 1874: pl. ii, figs 5, 6; Fig. 12C), is represented by fragments of the rostrum (Fig. 12A, B) and mandibular symphysis, both bearing median crests. The crests arise from the anterior tips of the jaws and are rather different in shape and proportions to those of other species of Loncho- dectes. Consequently, even if crests are a sexually dimorphic character it seems likely that at least two species of Lonchodectes are present in the Cambridge Greensand.

?Pteranodontidae: The principal representative of this family, Pteranodon, is well known from the Smoky Hill Chalk Member of the Niobrara Formation and the overlying Sharon Springs Member of the Pierre Shale of western North America and has been extensively reviewed by Bennett (1992, 1993, 1994, 2001). Pteranodontids are distinguished by their unusual skull morphology, with long, slender. pointed edentulous jaws, a crest that projects posterodorsally from the fronto-parictal region of the skull, and many other cranial and postcranial characters (Bennett 1994: 24). Nyctosaurus, another edentulous pterosaur from the Upper Cretaceous of the New World (Wellnhofer
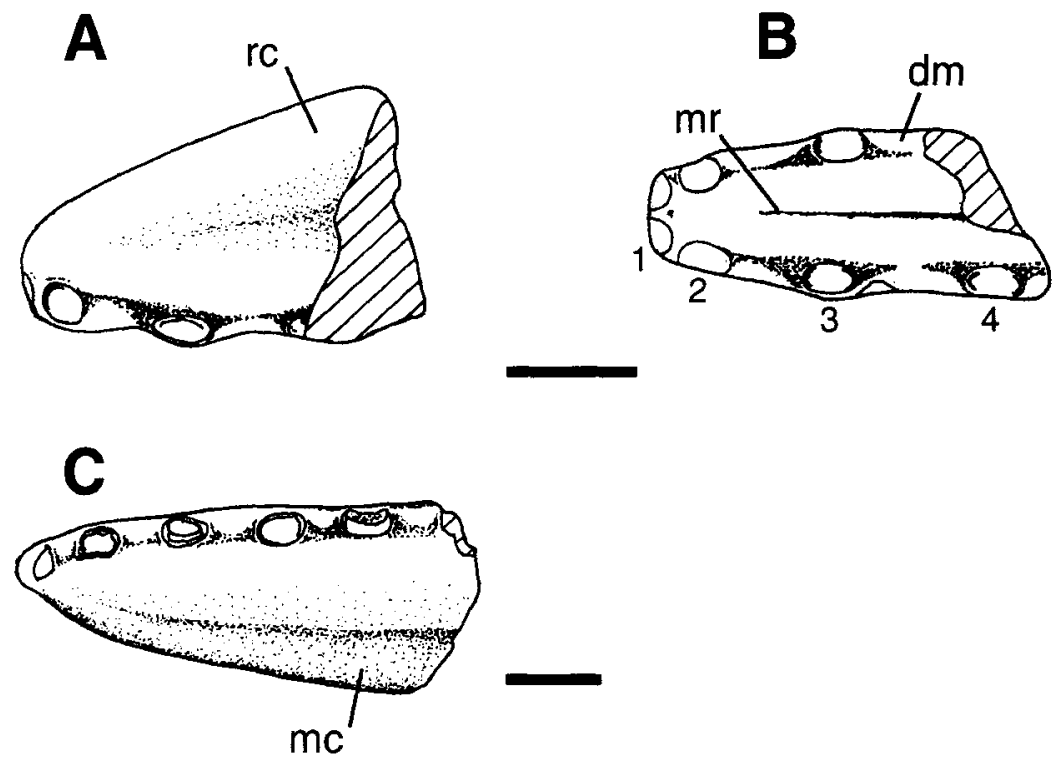

D
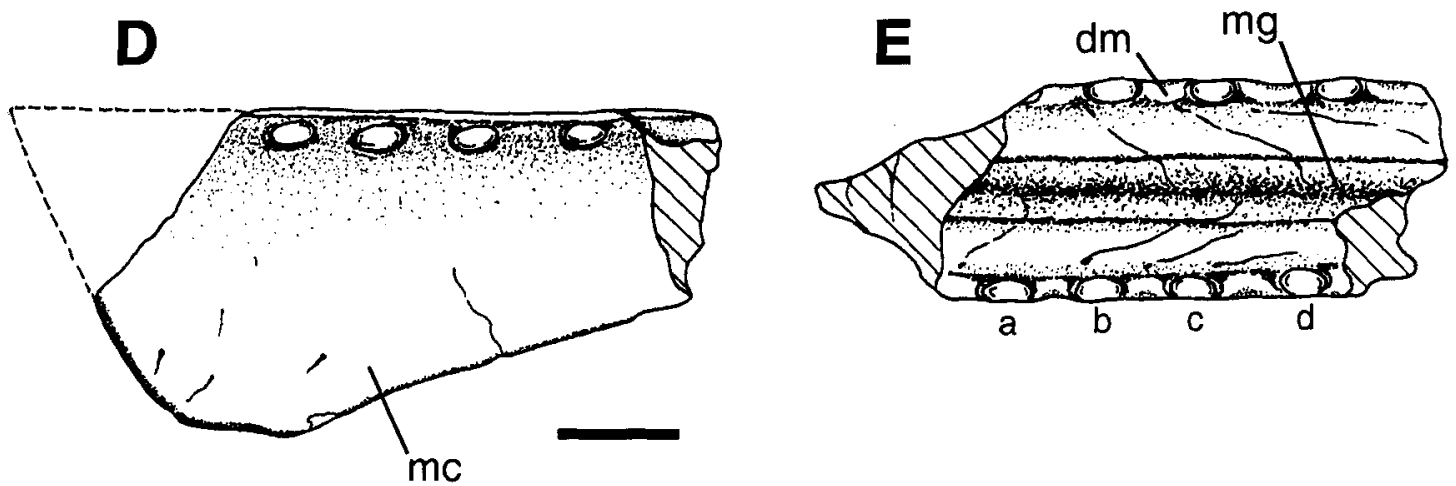

Fig. 12. Anterior end of a rostrum (YORM 1983/113F) of Lonchodectes platystomus in (A) left lateral and (B) ventral (palatal) view. Anterior end of a mandibular symphysis (BMNH 43074) of Lonchodectes platystomus in (C) left lateral view. Anterior end of the holotype mandibular symphysis (CAMSM B54.855) of Lonchodectes machaerorhynchus in (D) left lateral and (E) dorsal view. Abbreviations: a-d, positions of four dental alveoli; dm, dental margin; mc, mandibular crest; mg. mictline groove; mr, midline ridge; rc, rostral crest; $1-4$, positions of first four dental alveoli. Scale bar $=10 \mathrm{~mm}$. 
1991a) has often been included in the Pteranodontidae (e.g. Wellnhofer 1978), but recent studies (Bennett 1989. 1994. Unwin 1995. Unwin \& Lü 1997) suggest that it may not be as closely related to Pteranodon as some toothed taxa such as ornithocheirids. While most workers (e.g., Wellnhofer 1978) have confined the Pteranodontidae to Pterunodon and Nyctosaurus (though see above), Padian (1986) and subsequently Bennett $(1989,1994)$ expanded this family to include ornithocheirid: (Anhanguera. Santanadactylus, and possibly 'Criorhynchus'. 'Tropeognathus' and Ornithocheirus) and Istiodactylus (formerly $\mathrm{Or}$ nithodesmus, see Howse et al. 2001). This grouping is equivalent to Ornithocheiroidea (see Unwin \& Lü 1997) and here the Pteranodontidae is restricted to Fteranodon and another apparently closely related form, Ornithostoma.

The name Crnithostoma was first proposed by Seeley (1871) for a fragment of toothless jaw (CAMSM B54.485. Owen 1859b: pl. iv. figs 4-5: Fig. 13A-D) from the Cambridge Greensand. This fragment had been mentioned in the 'Index' (Seeley 1869a) as possibly from a toothless pterosaur, predatirg the first description of the edentulous jaws of Pteranodon (Marsh 1876) by some seven years. The Cambridge Greensand specimen was later made the holotype of Ornithostoma sedgwicki (Seeley 1891a). In his 1871 paper Seeley also mentioned two other specimens representing a toothless pterosaur, but these were not figured or described by Seeley. or later authors. A thc rough search of the collections in the Sedgwick Museum, Cambridge led to the discovery, in 1986, of two edentulous jaw fragments and it seems likely that these are the original specimens referred to by Seeley. Hooley (1914) also assigned various postcranial bones (fragmentary notaria, scapulocoracoids, type ' $\mathrm{B}$ ' humeri and ulnae, and group 1 femora) from the Cambridge Greensand to Ornithostoma, but there is no evidence to support this opinion.

Ornithostoma sedgwicki was a medium-sized pterosaur with elongate, edentulous jaws and probably no more than $2-3 \mathrm{~m}$ in wingspan. The rounded, triangular cross-section of the rostrum (Fig. 13B), which also has low, rounded, marginal ridges (Fig. 13C) clearly distinguishes Ornithostoma from azhdarchids wherein the rostra have concave lateral surfaces and lack marginal ridges on the jaws (Wellnhofer \& Buffetaut 1999: fig. 4). Ornithostoma is also distinct from Tapejara and Tupuxuara, which have prominent midline crests on the rostrum and the mandibular symphysis (Kellner \& Campos 1988, 1994, Kellner 1989. Wellnhofer \& Kellner 1991). By contrast. as Seeley (1901) noted, Ornithostoma shows some similarities to Pteranodon, especially in the cross-sectional profile of the rostrum and the presence of marginal ridges (Bennett 2001: figs 2, 3), although the latter are low and rounded in Ornithostoma, rather than narrow and relatively tall, as in Pteranodon. For the present. Ornithostoma is tentatively assigned to the Pteranodontidae. This determination appears to be supported by the presence, in the Cambridge
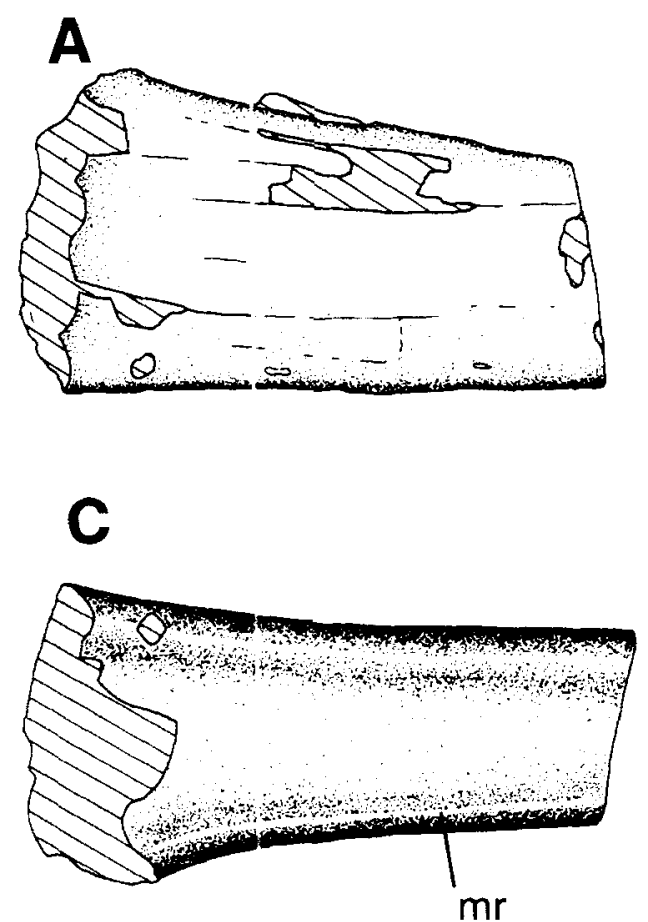

B

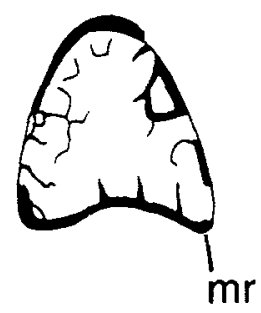

D

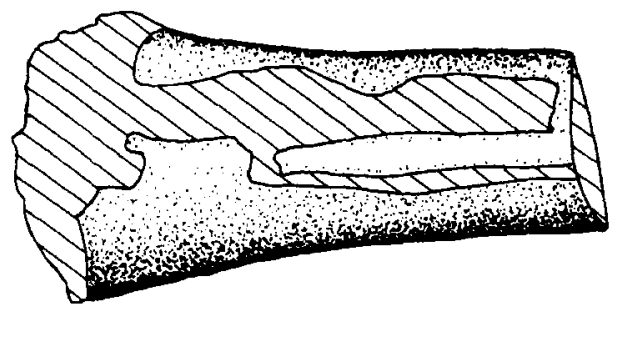

Fig. 13. Fragmentary holotype rostrum (CAMSM B54.485) of Ornithostoma sedgwicki in (A) right lateral, (B) anterior cross section, (C) ventral (palatal) and (D) dorsal view. Abbreviations: mr. marginal ridge. Scale bar $=10 \mathrm{~mm}$. 
Greensand, of a fragmentary cranium bearing the base of a tall, posterodorsally directed crest (CAMSM B54.406, Hooley 1914: pl. xxii, figs 1-3), supposedly a diagnostic character of Pteranodon (Bennett 1994) although, interestingly, this type of construction is evident in a new, as yet undescribed ornithocheirid from the Crato Formation of Brazil (Frey quoted in Viohl 2000: 30, see also pl. ix, fig. 4).

Summary: Systematic revision of the Cambridge Greensand pterosaur assemblage shows that of the 32 species named so far, only 10 are valid, although there may be one as yet unnamed species (Table 1). This probably represents an overestimate of true diversity because, in one case (Lonchodectes compressirostris and L. microdon), the two species are probably synonymous, although this cannot yet be demonstrated because of the lack of directly comparable material. In a second case (Ornithocheirus simus and Ornithocheirus sp.), the two species may represent disjunct populations of a single species in which intermediate forms are not yet known. In a number of other cases (Lonchodectes compressirostris and L. machaerorhynchus, Coloborhynchus capito and C. sedgwickii) taxa that are distinguished only by the presence or absence of crests may represent sexual dimorphs of a single species, as has been proposed for Pteranodon and other pterosaurs (Bennett 1992). Should all these putative synonymies eventually be demonstrated this would leave only seven species in the Cambridge Greensand. A further reduction in species diversity is unlikely, however, because the remaining taxa can be clearly distinguished from one another on the basis of dental and other characters.

\section{General significance of the Cambridge Greensand pterosaurs}

The Cambridge Greensand has yielded one of the most diverse pterosaur assemblages yet known (Wellnhofer 1991a), a statistic that remains true even if there was a minimum of seven species. The only Cretaceous locality that has produced a similar taxonomic diversity is the Lower Cretaceous Santana Formation of Brazil (Wellnhofer 1991c, Kellner 1991; Figs 1, 14), which in a recent paper (Kellner \& Tomida 2000 ) is accredited with 17 species (this does not include taxa from the Crato Limestone, which is a distinct and somewhat older unit - see Figs 1,
14). This total is inflated by taxonomic oversplitting and the retention of invalid taxa: when these are taken into account, the list is reduced to only ten species (Unwin et al. 2000: table 1) and true species diversity may have been even lower. Partly because of its taxonomic richness and the large number of individuals recovered. and partly due to its age and geographic location, the Cambridge Greensand pterosaur assemblage has played, and continues to play, a prominent role in the reconstruction of the evolutionary history of pterosaurs. Two aspects. the history of particular clades, and the ecology and palaeobiogeography of Cretaceous pterosaurs are discussed here in the light of our current understanding of this assemblage.

History of Cretaceous pterosaurs: Recent discoveries, for example in South America (Santana Formation, Crato Formation, Lagarcito Formation) and China (Tugulu Series, Yixian Formation), coupled with older records from Europe (Purbeck Limestone Formation, Hastings Sands, Cambridge Greensand) are informative regarding the history of pterosaurs in the Early Cretaceous (see Wellnhofer 1991a, Unwin et al. 2000; Figs 1, 14). By contrast, the Late Cretaceous pterosaur fossil record is more poorly known: there are no major assemblages such as those found in the Cambridge Greensand and Santana Formation and, apart from a few records such as that of $A z h d a r c h o$ from the Beleuta Svita of Uzbekistan (Nesov 1984, Bakhurina \& Unwin 1995), little is known about late Cenomanian-Santonian pterosaurs (Fig. 14). Consequently, the Cambridge Greensand and closely related, but slightly younger, Lower Chalk pterosaur assemblages of England are of special interest as they provide the last 'view' of several Early Cretaceous pterosaur clades, and possibly the first view of an important Late Cretaceous lineage, the Pteranodontidae (Fig. 14).

The Cambridge Greensand and Lower Chalk of Kent yield some of the youngest records for the Ornithocheiridae, a relatively long lived clade that is certainly known for almost the entire Early Cretaceous (Fig. 14) and probably originated in the Late Jurassic. The Cambridge Greensand contains possibly the youngest known record for Coloborhynchus, which extends back to at least the Valanginian. Coloborhynchus moroccensis from the Kem Kem beds of Morocco may represent an even younger record, but only if the age of the Moroccan deposits is accepted as Cenomanian, and not Albian. Ornithocheirus 


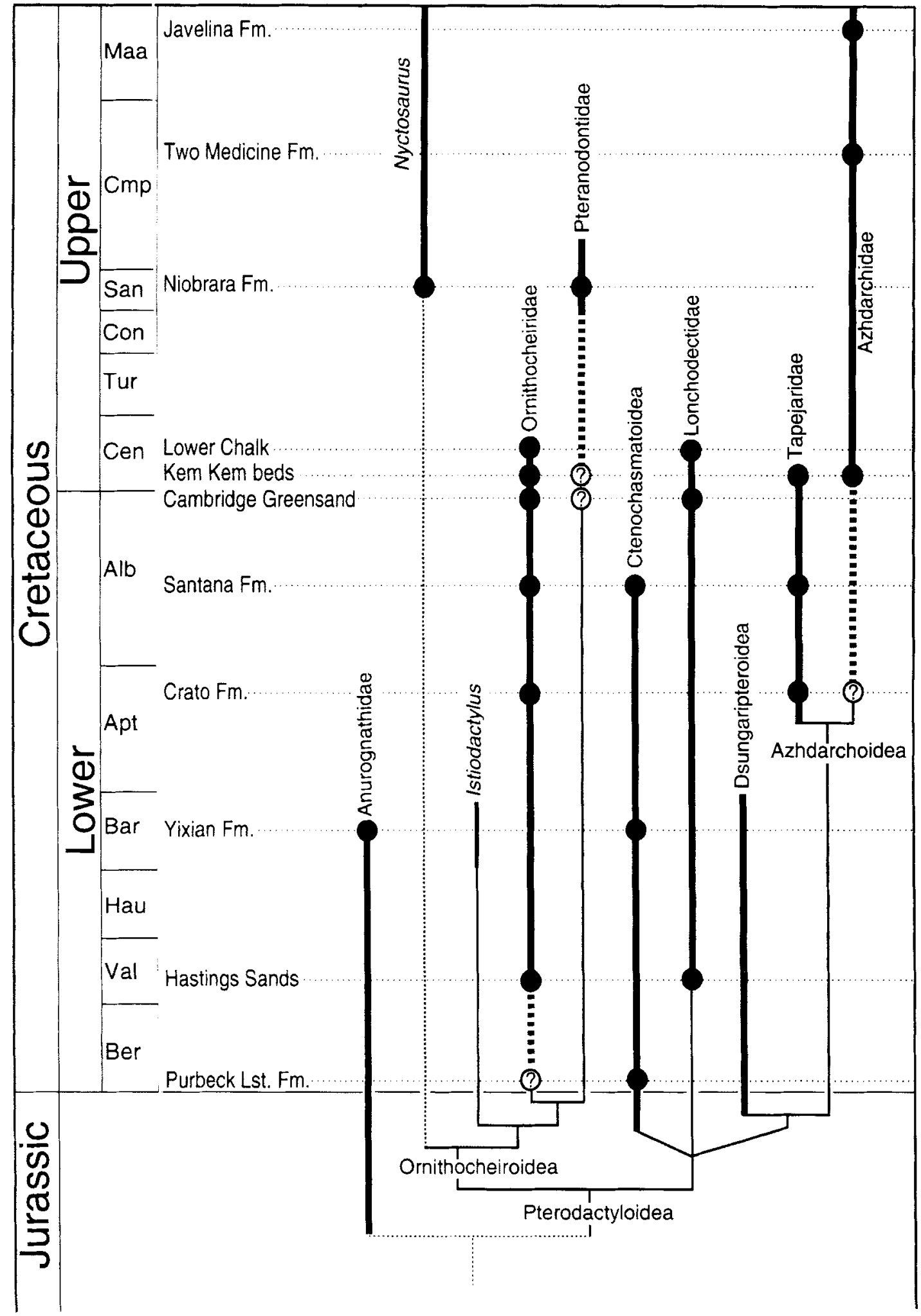

Fig. 14. Stratigrap lic distribution of important Cretaccous pterosaur assemblages and their relationship to the temporal history of the main clides of Cretaceous pterosaurs. Plwlogeny based on Unwin (1995). Unwin \& Lü (1997) and Unwin et al. (2600). and includ s only those clades that have a (retaceous record. Thick, solid lines indicate the known stratigraphic range of a particular clate. although fossil records mav not have been reported for all stages within that range. Thick. dashed lines indicate a possible range extension based on an unconfirmed record. or records. Thin solid lines indicate lineages predicted by the phylogenetic livpothesis adopted here. Thin dashed lines indicate uncertainty concerning the relationship of a clade to other taxa. Solid circles indicate a confirmed record for a particular assemblage. circles enclosing a question mark indicate an unconfirmed record. Abbreviations: Alb. Albian: Apt. Aptian: Bar. Barremian: Ber. Berriasian; Cen. Cenomanian; Con. Coniacian: Cmp. Car panian: Fm. Formation. Hau. Hatterivian. Lst. Limestone. Maa. Maastrichtian: San, Santonian; Tur, Turonian: Val. Vatangit ian. 
simus from the Cambridge Greensand is the youngest record for the genus, which is otherwise only certainly known from the Aptian. Anhanguera is well represented in the Cambridge Greensand and persisted into the Cenomanian where A. cuvieri, from the Lower Chalk of Kent, is the youngest record both for this genus and for the Ornithocheiridae (Fig. 14). Various mid to Late Cretaceous pterosaurs have been assigned to the Ornithocheiridae (see Wellnhofer 1991a), but none of these can be certainly demonstrated to have belonged to this family. Moreover, although the Late Cretaceous pterosaur record is relatively poor, as mentioned above, the absence of any definite post Cenomanian records for the Ornithocheiridae contrasts with the growing number of records from the Early Cretaceous and it seems likely that ornithocheirids became extinct early in the Late Cretaceous.

The presence of Lonchodectes sagittirostris in the Hastings Sands of Sussex, England, demonstrates that the Lonchodectidae were established by the Valanginian (Fig. 14), while records from the Gault Clay, Cambridge Greensand and Lower Chalk show that this family persisted throughout the rest of the Early Cretaceous and survived into the Cenomanian. The apparent absence of any younger records suggests that the clade became extinct sometime in the early Late Cretaceous.

The presence of Ornithostoma sedgwicki in the Cambridge Greensand is of special interest because, if it is indeed a pteranodontid, as suggested above, it is the earliest record for this clade. Pteranodontids are otherwise only certainly known from the Coniacian-Campanian interval (Bennett 1984, 2001), thus the Cambridge Greensand record represents a considerable range extension. This discovery, which is also supported by the tentative identification of a pteranodontid jaw fragment from the Cenomanian of Morocco (Wellnhofer \& Buffetaut 1999), is not unexpected because, if the Ornithocheiridae is the closest known sister group to Pteranodon (Bennett 1989, 1994, Unwin 1995, Unwin et al. 2000) the existence of this clade in the Early Cretaceous (Fig. 14) implies that the lineage leading to the Pteranodontidae must also have existed by this time, or possibly even earlier. Ornithostoma appears to have been much smaller than Pteranodon (wingspans of 4. $-6.25 \mathrm{~m}$, Bennett 2001) which suggests that the evolution of large size within Pteranodontidae occurred independently from the same trend in other clades such as Azhdarchidae.
Ecology and palaeobiogeography of Cretaceous pterosaurs: Comparison of the Cambridge Greensand pterosaur assemblage with other late Early and early Late Cretaceous pterosaur assemblages (Figs 1,14) provides some insights into the ecological diversity of Cretaceous pterosaurs. The Cambridge Greensand assemblage is dominated by medium to large probably piscivorous ornithocheirids, but also contains another relatively small, probably piscivorous form, Ornithostoma, and lonchodectids, small to medium-sized seemingly non-specialised pterosaurs. The Cambridge Greensand and underlying Gault Clay are shallow marine deposits and it seems likely that the Cambridge Greensand pterosaurs inhabited shallow shelf seas. feeding on fish and other aquatic prey caught from the surface of the water. The slightly younger Lower Chalk of Kent, England contains a smaller, but almost identical assemblage to the Cambridge Greensand (Figs 1, 14). This sequence also represents a shallow shelf sea. consequently the pterosaur assemblage from this deposit would seem to represent a continuation, into the early Cenomanian in the West European region, of a pterosaur community typically associated with a shallow marine environment.

The Kem Kem beds of the Ksar es Souk Province, Morocco (Fig. 15), interpreted as non-marine possibly deltaic deposits (Sereno et al. 1996). are approximately coeval with the Cambridge Greensand-Lower Chalk of England (Fig. 14). The Kem Kem assemblage shares some elements in common with the English pterosaur assemblages, notably the presence of ornithocheirids and perhaps pteranodontids (Mader \& Kellner 1997, 1999, Wellnhofer \& Buffetaut 1999; Fig. 1). Interestingly, the one identifiable ornithocheirid from the Kem Kem beds, Coloborhynchus, has generally been reported from deltaic (Paw Paw Formation, Hastings Sands) or lagoonal (Santana Formation) deposits, unlike other ornithocheirids which have often been found in marginal marine or fully marine deposits (Unwin et al. 2000). Lonchodectids have not, so far, been reported from the Kem Kem beds, but the latter have yielded an azhdarchid (Kellner \& Mader 1996. Wellnhofer \& Buffetaut 1999) and a species of Tapejara (Wellnhofer \& Buffetaut 1999), neither of which have been found so far in Albian-Cenomanian deposits of England. Tapejara has been interpreted as a frugivore (Wellnhofer \& Kellner 1991) which, if correct (a detailed analysis has yet to be carried out) means that this taxon inhabited continental environments. Azhdarchids 
have frequen ly (though not exclusively) been reported from continental deposits (Wellnhofer 1991a). but their feeding ecology: scavenger. wader or piscivo e. is still unclear (see Martill 1997. Prieto 1998 for discussion).

The differences in the composition of the English and Morcccan assemblages arc most readily interpreted as the result of ecological differentiation. The Kem Kem beds yield taxa. such as $T a$ pejara and azhdarchicls. that are typically found in continental or coastal deposits and that have been argued by some workers (Lawson 1975. Langston 198:. Wellnhofer \& Kellner 1991) to be adapted tc continental habitats. By contrast. the absence $o$ any large land masses in the vicinity of England in the late Albian (Fig. 15) is consistent with the presence of typically marine forms such as the ornithocheirid Anhanguera and the putative pteranodontid Omithostoma.

The pteroscur assemblage from the Santana Formation is somewhat similar to that from the Cambridge Greensand in that it too is dominated by ornilhocheirids (Figs 1. 14). Species of Ornithocheirus, Coloborhynchus and Anhanguera have all been reported from this deposit (Unwin et al. 2000) and. in most cases, are remarkably similar in size and morphology to the Cambridge Greensand taxa. By contrast, other Santana taxa such as the tapejarids Tapejara and Tupuxuara. and the ctenochasmatid Cearadactylus (Unwin et al. 2000) are not known from the Cambridge Greensand, while Lonchodectes is so far unknown from the Santana Formation. In some cases. such as Tapejara, this difference might be attributed to ecological differences, in that the Santana basin seems to have been a land-locked, or largely land-locked marine-brackish water basin (Martill 1993), into which putatively continental forms such as the supposedly frugivorous tapejarids may have fallen. In the case of Lonchodectes, however, its absence from the Santana Formation and indeed from any other Lower Cretaceous deposits other than those of England might reflect a degree of endemism.

In summary. at present it seems that the taxonomic distinctions apparent between the main late Early and early Late Cretaceous pterosaur assemblages cannot be attributed to evolution within clades, or to clade origin or extinction as nearly all the main clades persist throughout this interval (Fig. 14). Rather, the differences can be attributed to palaeoecological differentiation, although the restricted distribution of Lonchodectes also suggests the operation of some degree of endemism. Previously, Unwin et al. $(2000)$ outlined evidence for palaeoecological differentiation in Early Cretaceous pterosaurs, principally between marine and continental forms. The observations presented above support this conclusion.

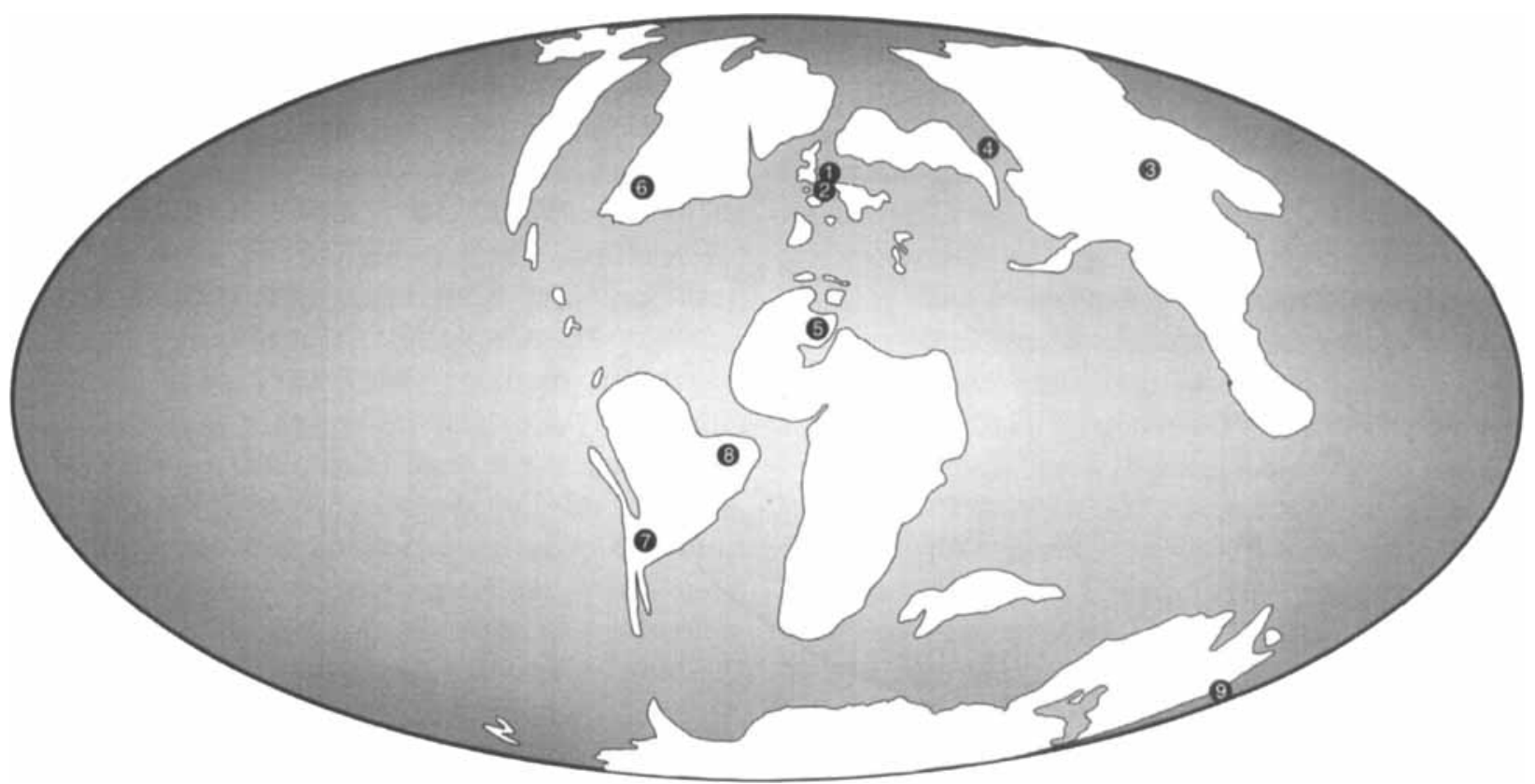

Fig. 15. Palacogeceraphic distribution of hate Early and carly Late Cretaceous pterosaur assemblages. Taxonomic composition of assemblages sh wn on Fig. 1. Palaeogeography based on Smith et al. 1994. Abbreviations: 1. Cambridge Greensand, England: 2. Lower Clalk. England: 3. Züünbayan Srita. Khuren-Dukh. Mongolia: 4. Lysaya Gora, Saratov, Russia; 5, Kem Kem red beds. Morocer: 6. Paw Paw Formation. Texas. LSA: 7. Lagarcito Formation. San Luis. Argentina: 8. Santana and Crato Formations. Ceara. Brazil: 9. Toolehuc Formation. Queensland. Australia. 


\section{Acknowledgements}

I am very grateful to the many museums and institute staff who gave me access to their collections, loaned out material and provided much useful information. Special thanks go to A. Milner, C. Walker, S. Chapman and the late A. Charig, The Natural History Museum, London, England, C. Forbes, S. Etchells-Butler, D. Norman and the late D. Price, Sedgwick Museum, Cambridge, England, H. Ivemey-Cook and A. Morter, British Geolgical Survey, Keyworth, England, J. Cooper, Booth Museum, Brighton, England, R. Eagar and J. Nudds, Manchester Museum, Manchester, England, P. Ensom. P. Manning and B. Pyrrah, Yorkshire Museum, York, England, D. Smith, Castle Museum, Norwich, England, I. Rolfe, S. Pearce and J. Liston, Hunterian Museum, Glasgow, Scotland, P. Wellnhofer, Bayerische Staatssammlung für Paläontologie. Munich, Germany, the late L. Nesov, Dept of Geology, St Petersburg University, Russia, W. Langston Jnr., University of Texas at Austin, Texas, USA, M. Manabe and Y. Tomida, National Science Museum, Tokyo, Japan, S. Nabana, Iwaki Museum of Coal and Fossils, Iwaki, Japan, Y. Hasegawa and Y. Takakua, Gunma Museum of Natural History, Gunma, Japan, Y. Okazaki and Y. Yabumoto, Kita-Kyushu City Museum of Natural History. Kita-Kyushu, Japan, H. Taru, Kanagawa Prefectural Museum of Natural History, Kanagawa, Japan, E. Gaffney, M. Norell and A. Kellner, American Museum of Natural History, New York, USA, E. Frey, Staatssammlung für Naturkunde, Karlsruhe, Germany and Z. Cai, Zhejiang Museum of Natural History, Hangzhou, China.

I thank N. Bakhurina, S. Bennett, M. Benton, M. Fastnacht, N. Fraser, E. Frey, G. Hazelhurst, S. Howse, A. Kellner, W. Langston Jnr., D. Martill, K. Padian, C. Walker and P. Wellnhofer, for many helpful discussions of the Cambridge Greensand pterosaur assemblage. The Department of Zoology, Reading University, Dept of Earth Sciences, Bristol University, the Royal Society and the British Council are thanked for funding aspects of this work. A. Jenkins and S. Powell assisted with the photography, T. Bergmann, S. Grimm, C. Finkenwirth and A. Schulz very kindly helped with the maps and line drawings and $\mathrm{R}$. Schoch translated the German abstract. I extend my best thanks to $M$. Romano (Sheffield University) for his advice and encouragement in the early stages of this project. I am very grateful to $\mathrm{N}$. Bakhurina, P. Barrett, S. Bennett, M. Benton, D. Martill, D. Naish and $P$. Wellnhofer for their constructive criticism of earlier versions of this paper, to N. Bardet and N. Fraser for help with literature and to G. Arratia for her editorial work on the MS. Finally, this paper is dedicated to the late Bev Halstead, who supervised my research from 1984-1991 and whose enthusiasm, encouragement, advice and support enabled this project to be started and, eventually, to be finished.

\section{References}

Arthaber, G. von 1922. Uber Entwicklung, Ausbildung und Absterben der Flugsaurier. - Paläontologische Zeitschrift 4: $1-47$.

Bakhurina, N. N. \& Unwin, D. M. 1995. A survey of pterosaurs from the Jurassic and Cretaceous of the former Soviet Union and Mongolia. - Historical Biology 10: 197-245.

Bardet, N. 1992. Stratigraphic evidence for the extinction of the ichthyosaurs. - Terra Nova 4: 649-656.

Bennett, S. C. 1989. A pteranodontid pterosaur from the Early Cretaceous of Peru, with comments on the relationships of Cretaceous pterosaurs. - Journal of Paleontology 63: $669-677$.

- 1992. Sexual dimorphism of Pteranodon and other pterosaurs with comments on cranial crests. - Journal of Vertebrate Paleontology 12: 422-434.
- 1993. The ontogeny of Pteranodon and other pterosaurs. - Paleobiology 19: 92-106.

- 1994. Taxonomy and systematics of the Late Cretaceous pterosaur Pteranodon (Pterosauria, Pterodactyloidea). Occasional Papers of the Natural History Museum, The University of Kansas, Lawrence, Kansas 169: 1-70.

- 2001. The osteology and functional morphology of the Late Cretaceous pterosaur Pteranodon. - Palaeontographica A 260: 1-153.

Bennison, G. M. \& Wright, A. E. 1978. The geological history of the British Isles. X $+406 \mathrm{pp}$., Edward Arnold. London.

Benton, M. J. \& Spencer, P. S. 1995. Fossil Reptiles of Great Britain. 386 pp., Chapman and Hall, New York.

Bonney, T. G. 1873. On the Upper Greensand or Chloritic Marl of Cambridgeshire. - Proceedings of the Geologists' Association 3: $1-20$.

Bowerbank, J. S. 1846. On a new species of Pterodactyl found in the Upper Chalk of Kent. - Quarterly Journal of the Geological Society of London 1 (5): 7-8.

- 1851. On the Pterodactyles of the Chalk formation. Proceedings of the Zoological Society of London: 14-20.

Bramwell, C. D. \& Whitfield, G. R. 1974. Biomechanics of Pteranodon. - Philosophical Transactions of the Royal Society of London (B) 267: 503-581.

Breistroffer, M. 1940. Revision des ammonites du Vraconien de Salazac (Gard) et considérations générales sur ce sous-étage albien. - Travaux de la Laboratoire de Géologique Université Grenoble 22: 1-101.

Buffetaut, E., Cappetta, H., Gayet, M., Martin, M., Moody, R. T. J., Rage, J. C., Taquet, P. \& Wellnhofer, P. 1981. Les vertébrés de la partie moyenne du Crétacé en Europe. Cretaceous Research 2: 275-281.

Buisonjé, P. H. de 1980. Santanadactylus brasilensis nov. gen. nov. sp., a long necked, large pterosaurier from the Aptian of Brasil. - Proceedings Koninkl Nederland Akademie Wetenschappen, B 83: 145-172.

Campos, D. de A. \& Kellner, A. W. A. 1985a. Panorama of the flying reptiles study in Brazil and South America. - Anais da Academia Brasileira de Ciências 57: $453-466$.

- 1985b. Um novo exemplar de Anhanguera blittersdorffi (Reptilia, Pterosauria) da formação Santana, Cretáceo Inferior do Nordeste do Brasil. - Boletim de Resumos, 9 Congresso Brasileiro de Paleontologia: 13.

Carter, D. J. \& Hart M. B. 1977. Aspects of mid-Cretaceous stratigraphical micropalaeontology. - Bulletin of the British Museum of Natural History (Geology) 29: 1-135.

Chapman, F. 1899. Foraminifera from the Cambridge Greensand. - Annals and Magazine of Natural History 73: 48-66 (part 1), 302-316 (part 2).

Chatwin, C. P. 1948. British Regional Geology. East Anglia and adjoining areas. IV + 99 pp.. HMSO, London.

Collins, J. I. 1970. Rhinochelys Seeley from the Upper Cretaceous of England and France. - Palaeontology 13 $355-378$.

Cookson I. C. \& Hughes N. F. 1964. Microplankton from the Cambridge Greensand (Mid-Cretaceous). - Palaeontology 7: $37-59$

Coombs, W. P., Jr. \& Maryañska, T. 1990. Ankylosauria. In Weishampel, D. B., Dodson, P. \& Osmólska, H. (eds). The Dinosauria: 456-483, University of California Press. Berkeley.

Cooper, M. R. \& Kennedy W. J. 1977. A revision of the Baculitidae of the Cambridge Greensand. - Neues Jahrbuch für Geologie und Paläontologie, Monatshefte 1977 (11): $641-658$.

Darby, H. C. 1938. The Cambridge Region. XII + 234 pp. Cambridge University Press, Cambridge.

Dennis, J. P. 1861. On the mode of flight of the pterodactyles of the coprolite bed near Cambridge. - Reports of the British Association for the Advancement of Science (1860): 76-77. 
Edmonds. E. A. d: Dinham G. H. 1965. Geology of the country around Huntingdon and Biggleswade. 90 pp. Memoirs of the Geolog cal Survey: U.K.. London.

Elzanowski. A. \& Galton. P. M. 1991. Braincase of Endiornis. an Early (retaceous bird from England. - Journal of Vertebrate Paleontolog: 11: 90-107.

Estes. R. 1983. Situria 1errestria. Amphisbaenia. In Wellnhofer. P. (ed.). Handbuch der Paläoherpetologic. Part 10A: 1-249, Gustar Fischer Verlag. Stuttgart.

Fastnacht. M. Ir press. First record of Coloborhwolus (Pterosauria) from the Santana Formation (Lower Cretaceous) of the (hapada do Araripe. Brazil. - Paläontologische Zeitsch ift 75

Fisher. O. 1873. Cn the phosphatic nodules of the Cretaceous rock of Cambidgeshire. - Quarterly Joumal of the Geological Society of London 28: 396-397.

Frey. E. \& Martil. D. M. 1994. A new perosaur from the Crato formation (Lower Cretaceous. Aptian) of Brazil. Neues Jahrbuch für Geologie und Paläontologic. Abhandlungen 194: 37 ) -412

Frey. E. \& Riess. I. 1981. A new reconstruction of the pterosaur wing. - Seues Jahrbuch für Geologie und Paliantologie, Abhandlungen 161: 1-27

Gallois. R. W. \& Vlorter. A. A. 1982. The Stratigraphy of the Gault of East Anglia. - Proceedings of the Geologists Association 93: $351-368$.

Gray. J. E. 1845. Catalogue of the Specimens of Lizards in the Collection of the British Museum - London. XXVII +289 pp.. Trustees of the British Museum (Natural History). London.

Grove, R. 1976. the Cambridgeshire coprolite mining rush. 51 pp. Oleander Press. Cambridge.

Hankin. E. H. \& Watson. D. M. S. 191t. On the flight of pterodactyls. - Aeronautical Journal 18: 32t-335.

Hart. M. B. 1973. Foraminiferal evidence for the age of the Cambridge Greensand. - Proceedings of the Geologists Association $8465-82$

Hawkes. L. 1943. The erratics of the Cambridge Greensand - their naturs. provenance and mode of transport. Quarterly Joumal of the Geological Society of London 99: $93-104$.

Head. J. J. 1998. A new species of basal hadrosaurid (Dinosauria. Ornithischia) from the Cenomanian of Texas. Journal of Veriebrate Paleontology 18: 718-738.

Hoolev. R. W. 1914. On the ornithosaurian genus Omithocheints. with a review of the specimens of the Cambridge Greensand in he Sedgwick Museum. - Annals and Magazine of Natural History 8 (13): 529-5.57.

Howse. S. C. B. 1866. On the cervical vertebrae of the Pierodactyloidea (Reptilia: Archosauria). - Zoological Journal of the Linnean Society 88: 307-328.

Howse. S. C. B. Milner. A. R. \& Martill. D. M. 2(0)1. Pterosaurs. In Mart 11. D. M. \& Naish. D. (eds). Dinosaurs of the Isle of Wight: 32t-335. The Palaeontological Association. London.

International Commission on Zoological Nomenclature. 1999. International Code of Zoological Nomenclature. th. Edit. $\mathrm{XXIX}+126 \mathrm{~F} p$. International Trust for Zoological Nomenclature. Netural History Muscum. London.

Jukes-Browne. A. J. 1875, On the relations of the Cambridge Gault and Gre ensand. - Quarterly Journal of the Geological Society of London 31: 256-316.

Kellner. A. W. A 1984. Ocorrência de uma mandíbula de pterosauria (Brasileodactlus araripensis, nov. gen. now. sp.) na formaç io Santana. Cretáceo da chapada do Araripe. Ceará. Biasil. - 33 Congresso Brasileiro de Geologia. Anais 2: $5 \% 8-590$.

- 1989. A new edentate pterosaur of the Lower Cretaceous from the Araipe Basin. Northeast Brazil. - Anais da Acadenia Brasileira de Ciencias $61(4):+39-+46$.

- 1990. Os réptei, voadores do Cretacéo Brasileiro. - Anuário do Istitute de Geociéncias. CCMN. UFRJ, ano 1989: $86-106$.
- 1991. The Santana Formation pterosaurs. Supplementary Notes and Comments. In Maisev, J. G. (ed.). Santana fossils: an illustrated atlas: $370-371$, T.F.H. Publications, Inc., Nepture Cily. New Jersey.

Kellner. A. W. A. \& Campos, D. de A. 1988. Sobre un novo pterosauro com crista sagital da Bacia do Araripe, Cretáceo Inferior do Nordeste do Brasil. - Anais da Academia Brasileira de Ciências 60 (4): 459-469.

- 1994. A new species of Tupuxuara (Pterosauria. Tapejaridae) from the Early Cretaceous of Brazil. - Anais da Academia Brasilcira de Ciências 66 (4): 467-473.

Kellner. A. W. A. \& Mader. B. R. 1996. First report of Pterosauria (Pterodactyloidea. Azhdarchidae) from Cretaceous rocks of Morocco, - Journal of Vertebrate Paleontology 16 (Suppl. lo nb. 3): 45A.

Kellncr. A. W. A. \& Tomida. Y. 2000. Description of a new species of Anhangueridae (Pterodactyloidea) with comments on the pterosaur fauna from the Santana Formation (Aptian-Albian), northeastern Brazil. - National Science Museum Monographs, Tokyo 17: 1-135.

Khozatskii L. E. \& Yur'ev. K. B. 1964. [Pterosauria]. In Orlov. Yu. A. (ed.). Osnovy Paleontologii 12: 589-603. [In Russian]

Kidwell. S. M. 1986. Models for fossil concentrations: paleobiologic implications. - Paleobiology 12: 6-24.

Kirkland. J. I. 1998. A new hadrosaurid from the Upper Cedar Mountain Formation (Albian-Cenomanian: Cretaceous) of eastem Utah - the oldest known hadrosaurid (Lambeosaurinae?). - New Mexico Museum of Natural History and Science. Bulletin 14: 283-295.

Kuhn. O. 1967. Die fossile Wirbeltierklasse Pterosauria. 52 pp. Ochen. Krailling bei München.

Langsion. W. 1981. Picrosaurs. - Scientific American 244 (2): $122-136$

Lawson. D. A. 1975. A pterosaur from the latest Cretaccous of West Texas: discovery of the largest flying creature. Science 187: 947-948.

Le Loeulf. J. 1993. European titanosaurids. - Revue de Pakéobiologic. Volume spécial 7: 105-117.

Lec. Y. N. 1994. The Early Cretaceous pterodactyloid pterosaur Coloborlynchus from North America. - Palaeontology 37: $755-763$.

Lott. G. K.. Knox. R. W.. Bigg. P. J., Davey, R. J. \& Morton, A. C. 1980. Aptian-Cenomanian stratigraphy in boreholes from offshore south-west England. - Report of the Institute of the Geological Sciences 80: 1-12.

Lydekker. R. 1888. Catalogue of the Fossil Reptilia and Amphibia in the British Museum (Natural History), Part $I$. The Orders Ornithosauria, Crocodilia, Dinosauria, Squamata. Rhynchocephalia and Proterosauria. 309 pp. Trustees of the British Museum (Natural History), London.

- 1889a. On remains of Eocene and Mesozoic Chelonia and a tooth of (?)Omithopsis. - Quarterly Journal of the Geological Society of London 45: 227-246.

- 1889b. Catalogue of the Fossil Reptilia and Amphibia in the British Muscum (Natural History), Part Il. The Orders Ichthyopterygia and Sauropterygia. 307 pp., Trustees of the British Museum (Natural History), London.

- 1904. Vertebrate paleontology. In Marr, J. E. \& Shipley, A. E. (eds). Handbook to the Natural History of Cambridgeshire: $51-70$. Cambridge University Press. Cambridge.

Madcr. B. I. \& Kellner. A. W. A. 1997. First occurrence of Anhangueridae (Pterosauria, Pterodactyloidea) in Africa. - Journal of Vertcbrate Paleontology 17 (Suppl. to nb. 3): 62A.

- 1999. A new anhanguerid pterosaur from the Cretaceous of Morocco. - Boletim do Museu Nacional, Genlogia, Nova Série. Rio de Janeiro 45: $1-11$.

Marsh. O. C. 1876. Notice of new sub-order of Pterosauria. - American Journal of Science (3) 1: 507-509.

Marshal. B. A. 1987. Osteopcltidae (Mollusca: Gastropoda) a new family of limpets associated with whale bone in deep sea. - Journal of Molluscan Studies 53: 121-127. 
Martill, D. M. 1993. Fossils of the Santana and Crato Formations, Brazil. $159 \mathrm{pp}$., Field Guides to Fossils No. 5. Palaeontological Association, London.

- 1997. From hypothesis to fact in a flight of fantasy: the responsibility of the popular scientific media. - Geology Today $13(2)$ : $71-73$.

Martill, D. M. \& Frey, E. 1998. A new pterosaur lagerstätte in N.E. Brazil (Crato Formation; Aptian, Lower Cretaceous): preliminary observations. - Oryctos 1: 79-85.

Martin, L. D. 1984. A new hesperornithid and the relationships of the Mesozoic birds. - Transactions of the Kansas Academy of Sciences 87: 141-150,

McGowan, C. 1972. The systematics of Cretaceous ichthyosaurs with particular reference to the material from North America. - Contributions to Geology 11 (1): 9-29.

McIntosh, J. S. 1990. Sauropoda. In Weishampel, D. B., Dodson, P. \& Osmólska H. (eds). The Dinosauria: 345-401, California University Press, Berkeley.

Morter A. A. \& Wood, C. J. 1983. The biostratigraphy of Upper Albian-Lower Cenomanian Aucinella in Europe. - Zitteliana 10: 515-529.

Nesov, L. A. 1984. [Upper Cretaceous pterosaurs and birds from Central Asia]. - Paleontologicheskii Zhurnal 1984 (1): 47-57. [In Russian].

Nopcsa. F. von 1924. Bemerkungen und Ergänzungen zu G. v. Arthaber's Arbeit über Entwicklung und Absterben der Pterosaurier. - Paläontologische Zeitschrift 6: 80-91.

Norman, D. B. \& Fraser, N. 1991. Phosphates, fossils and fens. - Conservation and the Cambridge Greensand. Earth Science Conservation 29: 30-31.

Norman, D. B. \& Weishampel. D. B. 1990. Iguanodontid and related ornithopods. In Weishampel, D. B., Dodson, P. \& Osmólska H. (eds). The Dinosauria: 510-533, California University Press, Berkeley.

Olshevsky. G. 1991. A revision of the parainfraclass Archosauria Cope, 1869, excluding the advanced Crocodylia. 196 pp.. Publications Requiring Research, San Diego.

Owen, H. G. 1979. Ammonite zonal stratigraphy in the Albian of North Germany and its setting in the Hoplitinid Faunal Province. - Aspekte der Kreide Europas, IUGS Series A 6: $563-588$.

Owen. R. 1846. On the supposed fossil bones of birds from the Wealden. - Quarterly Journal of the Geological Society of London 2: 96-102.

- 1851a. On a new species of pterodactyle (Pterodactylus compressirostris, Owen) from the Chalk; with some remarks on the nomenclature of the previously described species. - Proceedings of the Zoological Society of London: $21-34$.

- 1851b. Monograph on the fossil Reptilia of the Cretaceous Formations. - Monographs of the Palacontographical Society 1: 80-104.

- $1859 \mathrm{a}$. On remains of new and gigantic species of pterodactyle (Pter. fittoni and Pter. sedgwickii) from the Upper Greensand near Cambridge. - Reports of the British Association for the Advancement of Science 28 (1858): $98-103$.

- 1859b. Supplement (No. I) to the Monograph on the Fossil Reptilia of the Cretaceous Formations. - Monographs of the Palaeontographical Society: $1-19$.

- 1860a. On the orders of fossil and recent Reptilia and their distribution in time. - Reports of the British Association for the Advancement of Science 29 (1859): $153-166$.

- 1860b. On the vertebral characters of the order Pterosauria, as exemplified in the genera Pterodactylus (Cuvier) and Dimorphodon (Owen). - Philosophical Transactions of the Royal Society of London 149: 161-169.

- 1861. Supplement (No. III) to the Monograph on the fossil Reptilia of the Cretaceous Formations. - Monographs of the Palacontographical Society: 1-19.

1870. Monograph of the fossil Reptilia of the Liassic Formations. - Monographs of the Palaeontographical Society $27: 41-81$.
- 1874. Monograph on the Fossil Reptilia of the Mesozoic Formations - Monographs of the Palaeontographical Society: $1-14$.

Padian, K. 1984. A large pterodactyloid pterosaur from the Two Medicine Formation (Campanian) of Montana. Journal of Vertebrate Paleontology 4: 516-524.

- 1986. A taxonomic note on two pterodactyloid families. Journal of Vertebrate Paleontology 6: 289.

Penning, W. H. \& Jukes-Browne, A. J. 1881. The geology of the neighbourhood of Cambridge. - Memoirs of the Geological Survey, England and Wales. VI + 184 pp.. HMSO, London

Pereda-Suberbiola, X. \& Barrett, P. M. 1999. A systematic review of ankylosaurian dinosaur remains from the $\mathrm{Al}$ bian-Cenomanian of England. In Unwin, D. M. (ed.). Cretaceous fossil vertebrates. Special Papers in Palacontology 60: 177-208. Palaeontological Association. London.

Persson, P. O. 1963. A revision of the classification of the Plesiosauria with a synopsis of the stratigraphical and geographical distribution of the group. - Acta Universitatis Lundensis N. F. 59: $1-60$.

Plieninger, F. 1930. Pterosauria, In Pompeckj. J. F. (ed.). Fossilium Catalogus 1. Animalia, part 45: 1-84, W. Junk. Berlin.

Pricto, I. R. 1998. Functional morphology and fceding habits of Quetzalcoatlus (Pterosauria). - Coloquios de Paleontología 49: 129-144.

Rawson, P. F., Curry, D., Dilley. F. C., Hancock. J. M., Kennedy, W. J., Neale, J. W., Wood, C. J. \& Worssam, B. C. 1978. A correlation of Cretaceous rocks in the British Isles. - Gcological Society of London, Special Report 9: $1-70$.

Reed, F. R. C. 1897. A handbook to the geology of Cambridgeshire. X + 276 pp. Cambridge University Press. Cambridge.

Romer, A. S. 1966. Vertebrate paleontology. 3rd Edit. VIII + 468 pp., University of Chicago Press. Chicago.

Schäfer, W. 1962. Aktuo-Paläontologie nach Studien in der Nordsee. VIII + 666 pp., Verlag Waldemar Kramer. Frankfurt am Main.

Sedgwick, A. 1846. On the geology of the neighbourhood of Cambridge, including the formations between the Chalk escarpment and the Great Bedford level. - Transactions of the British Association for the Advancement of Science (1845): 40-47.

Seeley, H. G. 1864a. On pterodactyles, and on a new species of Pterodactylus machaerorhynchus. - Proceedings of the Cambridge Philosophical Society (1864): 228.

- 1864b. On the osteology and classification of Pterodactyles, Part II, with descriptions of the new species $P$. Hopkinsi and P. Oweni. - Proceedings of the Cambridge Philosophical Society (1864): 228.

- 1864c. On Saurornia and the classification of Pterodactyles, Part III. - Proceedings of the Cambridge Philosophical Society (1864): 228

- 1865a. On the literature of English pterodactyles. - Annals and Magazine of Natural History 3 (15): 148-153.

- 1865b. On the pterodactyle as evidence of a new subclass of Vertebrata (Saurornia). - Report of the British Association for the Advancement of Science 34 (1864): 69.

- 1866a. An epitome of the evidence that pterodactyles are not reptiles, but a new subclass of vertebrate animals allied to birds (Saurornia). - Annals and Magazine of Natural History 3 (17): 321-331.

- 1866b. The rock of the Cambridge Greensand. - Geological Magazine 3: 302-307.

- 1869a. Index to the fossil remains of Aves, Ornithosauria and Reptilia, from the Secondary System of Strata arranged in the Woodwardian Museum of the University of Cambridge. XXIII + 143 pp.. Deighton. Bell \& Co., Cambridge.

- $1869 \mathrm{~b}$. On the bird-like characters of the brain and metatarsus in the Pterodactylus from the Cambridge Green- 
sand. - Proceedings of the Cambridge Philosophical Society (1869): 1:9-130.

- 1870. The Ornithosauria: an elementary study of the bones of pterodactyles. made from fossil remains found in the Cambridg: Upper Greensand. and arranged in the Woodwardian Museum of the University of Cambridge. XII + 135 pp., Deighton. Bell \& Co.. Cambridge.

- 1871. Additional evidence of the structure of the head in ornithosaurs rom the Cambridge Upper Greensand: being a suppl zment to .. The Ornithosauria". - Annals and Magazine of Natural History 7 (37): 20-36.

- 1873. On Cetathrosaturus walkeri (Seeley) an ichthyosaurian from the Cambridge Upper Greensand. - Quarterly Journal of the Geological Society of London 29: 505-507.

- 1874. On cervical and dorsal vertebrac of Crocodilus cantabrigiensis (Srelcy) from the Cambridge Greensand. Quarterly Jou nal of the Geological Society of London 30: $693-695$

- 1876a. On th 2 organisation of the Ornithosauria. Zoological Journal of the Linnean Society 13: 84-107.

- 1876b. On the British fossil Cretaceous birds. - Quarterly Jounal of the Geological Society of London 32: 496-512.

- 1876c. On an cssociated series of cervical and dorsal ver tebrae of Poluptychodon, from the Cambridge Upper Greensand. in the Woodwardian Museum of the University of Cambriıge. - Quarterly Journal of the Geological Society ol Lon Jon 32: $433-436$

- 1876d. On Marrurosaurus semmus (Seeley). a long tailed animal with procoelous vertebrae from the Cambridge Upper Greensand preserved in the Woodwardian $\mathrm{Mu}$ seum of the Lniversity of Cambridge. - Quarterly Journal of the Geo ogical Society of London 32: 440-444.

- 1879. On the [rinosauria of the Cambridge Greensand. Quarterly Joum nal of the Geological Society of London 35: $591-635$.

- 1881. On evidence of two ornithosaurians referable to the genus Ornithccheirus. from the Upper Greensand of Cambridge. priserved in the collection of W. Reed. Esq.. F. G. S. - Geo ogical Magazine 8: 13-20.

- 1887. On Patri osaurus merocratus. Seelev. a lizard from the Cambridgc Greensand. preserved in the Woodwardian Museum of the University of Cambridge. - Quarterly Journal of the Geological Society of London 43: $216-219$.

- 1891a. The orn thosaurian pelvis. - Annals and Magazine of Natural History 6 (7): 237-255.

- 1891b. On the shoulder girdle in Cretaceous Ornithosauria. - Annals and Magazine of Natural History 6 (7): $438-445$.

- 1901. Dragons if the air. An account of extinct flying reptiles. XIII + 23') pp. Methuen. London.

Sereno. P. C.. Becli. A. L., Dutheil. D. B.. Gado. B.. Larsson, H. C. E. Lyor G. H. Marcot. J. D.. Rauhut. O. W. M. Sadleir. R. W., Sidor. C. A., Varricchio. D. D.. Wilson. G. P. \& Wilson, J. A. 1998. A long-snouted predatory dinosaur from Africa and the cvolution of the spinosaurids. Science 282: 1298-1302.

Short. G. H. 1914. Wing adjustments of pterodactyls. Aeronautical Journal 18: $336-342$.

Smith. A. G.. Smi.h. D. G. \& Funnell. B. M. 1994. Atlas of Mesozoic and Cenozoic coastlines. IX + 99 pp.. Cambridgc Univers ty Press. Cambridge.

Sollas. W. J. 1872. Some observations on the Upper Greensand formation of Cambridge. - Quarterly Joumal of the Geological Soc ety of London 28: 397-402.

- 1873. On the coprolites of the Upper Greensand formation. and on flints. - Quarterly Journal of the Geological Society of London 29: 76-81.

- 1876. On the glauconitic granules of the Cambridge Greensand. - (jeological Magazine 2 (3): 539-544.

Sollas. W. J. \& Jukes-Browne. A. J. 1873. On the included rock-fragments of the Cambridge Upper Greensand. Quarterly Jour al of the Geological Society of London 29: $11-16$.
Spath. L. F. 1923-1943. A monograph of the ammonoidea of the Gault. - Monographs of the Palaeontographical Society of London, volumes 1 \& 2: $787 \mathrm{pp}$.

Unwin. D. M. 1988. New pterosaurs from Brazil. - Nature 332: $398-399$.

- 1991. The morphology, systematics and evolutionary history of pterosaurs from the Cretaceous Cambridge Greensand of England. 527 pp., Ph.D. thesis, Department of Zoology. Reading University.

- 1995. Preliminary results of a phylogenetic analysis of the Pterosauria (Diapsida: Archosauria). In Sun Ailing \& Wang Yuanqing (eds). Sixth Symposium on Mesozoic Terrestrial Ecosystems and Biota. Short Papers: 69-72. China Ocean Press. Beijing.

Unwin. D. M. \& Bakhurina, N. N. 2000. Pterosaurs from Russia. Middle Asia and Mongolia. In Benton, M. J., Shiskin, M. Unwin, D. M. \& Kurochkin, E. (eds). The Age of Dinosaurs in Russia and Mongolia: 420-433, Cambridge University Press, Cambridge.

Unwin. D. M. \& Lü Junchang 1997. On Zhejiangopterus and the relationships of pterodactyloid pterosaurs. - Historical Biology 12: 199-210.

Unwin. D. M.. Lü Junchang \& Bakhurina, N. N. 2000. On the systematic and stratigraphic significance of pterosaurs from the Lower Cretaceous Yixian Formation (Jehol Group) of Liaoning. China. - Mitteilungen Museum für Naturkunde Berlin, Geowissenschaftliche Reihe 3: $181-206$

Veldmeijer. A. J. 1998. The Leiden specimen of Coloborhynchus (Pterosauria). In Abstracts of the Third European Workshop on Vertebrate Paleontology, Maastricht, 6-9 May 1998: 69.

Viohl. G. 2000. Drachen der Lüfte. Entwicklung and Leben der Flugsaurier. Führer zur gleichnamigen Ausstellung des Jura-Museums 9. Juni 2000 bis 7. Januar 2001: 48 pp. Verlag Dr. F. Pfeil, München.

Watson. D. M. S. 1974. Pterodactyls past and present. - Philosophical Transactions of the Royal Society of London B 267: $583-585$.

Welles. S. P. 1962. A new species of elasmosaur from the Aptian of Colombia and a review of the Cretaceous plesiosaurs. - University of California Publications in Geological Science 44: 1-93.

Wellnhofer, P. 1968. Über Pterodactylus kochi (Wagner, 1837). - Neues Jahrbuch für Geologie und Paläontologie, Abhandlungen 132 (1): 97-126.

- 1970. Die Pterodactyloidea (Pterosauria) der OberjuraPlattenkalke Süddeutschlands. - Abhandlungen der Bayerischen Akademie der Wissenschaften zu München, Mathematisch-Naturwissenschaftliche Klasse 141: 1-133.

- 1975. Die Rhamphorhynchoidea (Pterosauria) der Oberjura-Plattenkalke Süddeutschlands. II. Systematische Beschreibung. - Palaeontographica A 148: 132-186.

- 1978. Pterosauria. In Wellnhofer, P. (ed.). Handbuch der Paläoherpetologie. Teil 19: 82 pp., Gustav Fischer Verlag, Stuttgart.

- 1985. Neue Ptcrosaurier aus der Santana Formation (Apt) der Chapada do Araripe, Brasilien. - Palaeontographica A 187: 105-182.

- 1987. New crested pterosaurs from the Lower Cretaceous of Brazil. - Mitteilungen der Bayerischen Staatssammlung für Paläontologie und historische Geologie 27: $175-186$.

- 1991a. The Illustrated Encyclopedia of Pterosaurs. 192 pp.. Salamander Books, London.

- 1991b. Weitere Pterosaurierfunde aus der Santana-Formation (Apt) der Chapada do Araripe. Brasilien. - Palaeontographica A 215: 43-101.

- 1991c. The Santana Formation ptcrosaurs. In Máisey, J. G. (ed.). Santana fossils: an illustrated atlas: $351-370$. T.F.H. Publications Inc. Neptune City, New Jersey.

Wellnhofer. P. \& Buffetaut. E. 1999. Pterosaur remains from the Cretaceous of Morocco. - Paläontologische Zeitschrift 73: $133-142$. 
Wellnhofer, P. \& Kellner, A. W. A. 1991. The skull of Tapejara wellnhoferi Kellner (Reptilia: Pterosauria) from the Lower Cretaceous Santana Formation of the Araripe Basin, Northeastern Brazil. - Mitteilungen der Bayerischen Staatssammlung für Paläontologie und historische Geologie 31: $89-106$.

White, H. J. O. 1932. The geology of the country near Saffron Walden. Memoirs of the Geological Survey of the United Kingdom.

Williston, S. W. 1895. Note on the mandible of Ornithostoma. - Kansas University Quarterly 4: 61.

- 1896. On the skull of Ornithostoma. - Kansas University Quarterly 4: 195-197.

- 1897. Restoration of Ornithostoma (Pteranodon). - Kansas University Quarterly 6: $35-51$.
Witmer, L. 1990. The craniofacial airsac system of Mesozoic birds. - Zoological Journal of the Linnean Society 100: $327-378$.

Woods. H. 1891. Catalogue of the type fossils in the Woodwardian Museum, Cambridge. XIV +180 pp.. Cambridge University Press, Cambridge.

Woodward, A. S. 1893. Some Cretaceous pycnodont fishes. Geological Magazine 3 (10): 433-487.

- 1895. A synopsis of the remains of ganoid fishes from the Cambridge Greensand. - Geological Magazine 4 (2): 207.

Worssam B. C. \& Taylor, J. H. 1969. Geology of the country around Cambridge. 152 pp., Memoirs of the Geological Survey of Great Britain.

Zittel, K. von 1890. Handbuch der Paläontologie. 1. Abt. Paläozoologie, Bd. 3, Vertebrata: 773-804. R. Oldenbourg. München und Leipzig.

\section{Note added in proof}

Haopterus gracilis, a relatively small ( $1.35 \mathrm{~m}$ wingspan) pterodactyloid was recently described by Wang and Lü (2001) from the Yixian Formation (Lower Cretaceous: Barremian) of western Liaoning, China and assigned to the Pterodactylidae. Haopterus lacks apomorphies of Ctenochasmatoidea (Pterodactylidae + Ctenochasmatidea, sensu Unwin et al. $2000)$, such as an almost horizontal quadrate and associated complex of characters (Unwin \& Lü 1997), but exhibits two ornithocheiroid apomorphies (coracoid longer than scapula, metatarsal $<25 \%$ length of humerus) and a character complex diagnostic of ornithocheirids (first three pairs of premaxillary teeth increase in size posteriorly, while the fourth is relatively small). Moreover, it is consistent in other respects with ornithocheiroid anatomy (e.g. wing-metacarpal of similar length to the humerus). Haopterus appears to be the smallest adult ornithocheirid known so far, and one of the earliest representatives of this clade (cf. Fig. 14), and may indicate that the large sizes achieved by some Cambridge Greensand ornithocheirids occurred independently from that in other ornithocheiroids (Istiodactylus, pteranodontids) or other pterodactyloid clades.

Wang Xiaolin \& Lü Junchang 2001. Discovery of a pterodactylid pterosaur from the Yixian Formation of western Liaoning, China. - Chinese Science Bulletin 46 (13): $1112-1117$ 